\title{
Voices of Płaszów: The Impact of Schindler's List on a Former Concentration Camp
}

Jordan L. Riggs

joriggs@mix.wvu.edu

Follow this and additional works at: https://researchrepository.wvu.edu/etd

Part of the European History Commons, Holocaust and Genocide Studies Commons, and the Public History Commons

\section{Recommended Citation}

Riggs, Jordan L., "Voices of Płaszów: The Impact of Schindler's List on a Former Concentration Camp" (2020). Graduate Theses, Dissertations, and Problem Reports. 7679.

https://researchrepository.wvu.edu/etd/7679

This Thesis is protected by copyright and/or related rights. It has been brought to you by the The Research Repository @ WVU with permission from the rights-holder(s). You are free to use this Thesis in any way that is permitted by the copyright and related rights legislation that applies to your use. For other uses you must obtain permission from the rights-holder(s) directly, unless additional rights are indicated by a Creative Commons license in the record and/ or on the work itself. This Thesis has been accepted for inclusion in WVU Graduate Theses, Dissertations, and Problem Reports collection by an authorized administrator of The Research Repository @ WVU. For more information, please contact researchrepository@mail.wvu.edu. 
Graduate Theses, Dissertations, and Problem Reports

2020

Voices of Płaszów: The Impact of Schindler's List on a Former Concentration Camp

Jordan L. Riggs

Follow this and additional works at: https://researchrepository.wvu.edu/etd

Part of the European History Commons, Holocaust and Genocide Studies Commons, and the Public History Commons 
Voices of Płaszów:

The Impact of Schindler's List on a Former Concentration Camp

\title{
Jordan Riggs
}

\author{
Thesis submitted \\ to the Eberly College of Arts and Sciences \\ at West Virginia University \\ in partial fulfillment of the requirements for the degree of \\ Master of Arts \\ in History
}

\author{
Robert Blobaum, Ph.D., Chair \\ Melissa Bingmann, Ph.D. \\ Joshua Arthurs, Ph.D. \\ Department of History
}

Morgantown, West Virginia

2020

Keywords: Płaszów, Schindler’s List, Holocaust tourism, Film tourism, Memory, Landscape

Copyright: 2020 Jordan Riggs 


\author{
ABSTRACT \\ Voices of Płaszów: \\ The Impact of Schindler's List on a Former Concentration Camp \\ Jordan Riggs
}

Steven Spielberg's Schindler's List drew international attention to the site of Płaszów, a former Nazi concentration camp in Poland near the city of Kraków. This increased attention on the site impacted the area, leading to an increase in film-tourism, shown both in organized tours and published guidebooks. The site and film also held a personal connection to two sets of individuals, the descendants of Nazi commandant Amon Goeth and Holocaust survivors, which often prompted them to return to the site and push for more interpretation. This thesis addresses the lasting impact of the film on the site and the site's ongoing issues. While the landscape did have one large monument and a few smaller ones, interpretative panels to provide historical context to the site were not added until recently. This assessment of the film's impact on the site will reveal how a neglected landscape became transformed into a major project for The Historical Museum of the City of Kraków. While this project is a welcome addition for a site that has been ignored, it is also lacking proper interpretation signage, clear rules for visitor behavior, and security. 


\section{Table of Contents}

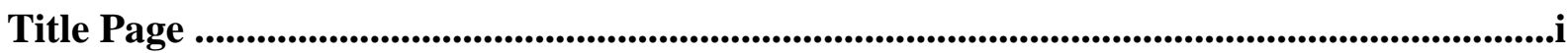

Abstract...................................................................................................................................................ii

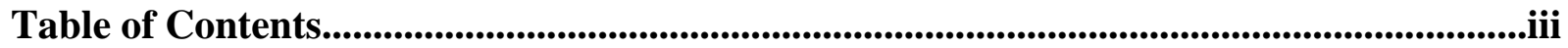

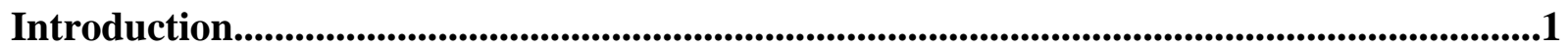

Chapter 1: Spielberg Presents Plaszów to the World.................................................10

Chapter 2: Personal Relevance of the Site and Film to Individuals ....................................31

Chapter 3: The Film's Lasting Impact on the Site Today....................................................47

Conclusion......................................................................................................................................61

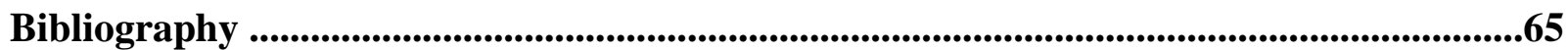




\section{Introduction}

Płaszów, the site of a former Nazi concentration camp in southern Poland near the city of Kraków, plays an important role in collective memory and remembrance for local Poles and international visitors. Featured in Steven Spielberg's 1993 film Schindler's List, Płaszów is often associated with two individuals, Amon Goeth, also spelled Göth, and Oskar Schindler. In the film Goeth, the camp commandant known for his cruelty, was a foil for Schindler's character, recognized as Righteous Among the Nations by Yad Vashem for his actions in saving Jews.

The camp's construction began in fall of 1942 using the forced labor of Jews from the Kraków ghetto. The last transfer of Jews from the ghetto to the Płaszów forced labor camp occurred in the summer of 1943. It was converted into a concentration camp on January 10 , 1944. By the summer of that year, the number of prisoners reached 25,000. The Germans arrested Amon Goeth on September 13, 1944 for "his black-market activities and currency violations." Arnold Büscher replaced Goeth as the camp's commandant and remained in that position until its closing. The last transport from Płaszów to Auschwitz occurred on January 14, 1945. Thirteen days later, Soviet troops liberated Auschwitz. ${ }^{1}$

Prior to the construction of the forced labor camp, the site's grounds were comprised of two Jewish cemeteries. One dated back to 1887 and the second one had just opened in 1932. Survivor Bernard Offen explained later that his brothers were two of the workers ordered to destroy the gravesites and witnessed the destruction of their own grandfather's grave. The gravestones were crushed and used as gravel or laid flat to serve as camp roads. ${ }^{2}$

\footnotetext{
${ }^{1}$ Mieczysław Pemper, Viktoria Hertling, and Marie Elisabeth Müller, The Road to Rescue: The Untold Story of Schindler's List (New York: Other Press, 2008), 208-210.

${ }^{2}$ Bernard Offen and Norman G Jacobs, My Hometown Concentration Camp: A Survivor's Account of Life in the Kraków Ghetto and Płaszów Concentration Camp, Library of Holocaust Testimonies (London: Vallentine Mitchell, 2008), 72-73.
} 
The purpose of this study is to investigate the impact of Schindler's List on the popular perception of the former concentration camp Płaszów. When Steven Spielberg filmed Schindler's List, he made some changes that affected the viewer's understanding of the physical site. Spielberg constructed 34 barracks and watchtowers as a set in the nearby Liban Quarry, a site where 800 Jews from Płaszów were assigned as forced laborers. After filming, some pieces of the set remained, which led to the mixing of historical artifacts with artifice from the 1993 movie. Without interpretation, this area often confuses visitors, as they wrongly assume that they have stumbled upon a hidden piece of the camp's remains. ${ }^{3}$ One of the few structures remaining from the camp is the Grey House. Originally belonging to the Jewish community, it served as Goeth's office and housed several SS officers. The building was known for its cruel punishments, including its solitary confinement cells and "standing bunkers," which provided a small space that forced the prisoners to remain vertical for the duration of their confinement. Extending for hours or even days, this cruel treatment was exhausting for those forced to endure it. $^{4}$

The Płaszów landscape involved varying historical uses including two Jewish cemeteries, forced labor camp, concentration camp, and postwar film set before it became the modern-day memorial and nature preserve. By critically assessing the growth of film tours and guidebooks, I will establish how Spielberg brought this former concentration camp to international fame. While it achieved world-wide attention due to the film, the lack of interpretation of the historical site has allowed locals to ignore its dark past. The reader should gain a clear picture of how Spielberg’s film influenced Płaszów’s development into its current memorial status. It will show

\footnotetext{
3 "Liban Quarry," In Your Pocket: Essential City Guide, January 20, 2019, accessed February 01, 2019; https://www.inyourpocket.com/krakow/liban-quarry_49806v.

4 "Grey House," In Your Pocket: Essential City Guide, March 20, 2019, accessed April 01, 2019; https://www.inyourpocket.com/krakow/grey-house_112729v.
} 
that Spielberg's decision to film near Płaszów led to an increase in tourism, preservation, and interpretation. In addition, it also provided opportunities for Goeth's descendants to learn about their family past and for the camp survivors to voice their story. Without Schindler's List, the area may have remained without proper signage or historical interpretation panels.

\section{$\underline{\text { Literature Review }}$}

While there are many sources about other World War II-era forced-labor and concentration camps, Płaszów has remained largely neglected in scholarship and ignored in visitation. The movie Schindler's List draws attention to the site and survivors have published a few memoirs, but their experience at Płaszów is usually portrayed as prelude to better known camps, such as Auschwitz-Birkenau. For example, Bernard Offen's account in My Hometown Concentration Camp details his experience as a prisoner from 1943 thorough the liquidation of the camp in fall of the following year. Then his account continues to his experience at Auschwitz. Mieczysław Pemper's The Road to Rescue is incredibly detailed in documenting the daily activities and functions of the camp. Pemper served as the "involuntarily recruited personal stenographer and secretary” of Amon Goeth, Płaszów’s commandant. Because of his unique position, he had access to classified SS documents, witnessed the relationships between Goeth and the SS men stationed at the camp, and developed his own personal relationship with Oskar Schindler. 5

Elinor Brecher's Schindler's Legacy includes accounts from thirty-one individuals or couples who were on Schindler's list. While their accounts do seem to paint a rosy image of Schindler, they include only small details about their experiences at Płaszów. Murray Pantierer detailed an account of how men were separated from women and children upon arrival because

\footnotetext{
${ }^{5}$ Pemper et al, $\mathrm{x}$.
} 
only men were used for their labor. ${ }^{6}$ Henry Wiener explained how after a plane crashed near an empty barrack, workers who had been staying at Schindler's "Emalia" factory had to return to living in the camp and walk to work. He also received a KL tattoo, but scrubbed it so hard that he had to pencil over it when he was inspected. ${ }^{7}$ Sam Birenzweig tells of how his experience changed after he left the camp to work under the authority of the Gestapo as part of a road crew. When he returned to the camp, the black market of food was thriving with "luxury items like vodka and salami." ${ }^{\prime 8}$ Regardless of the first-hand accounts in My Hometown Concentration Camp and Schindler's Legacy, Płaszów lacks a comprehensive historical narrative.

Historians have long studied the historical context and development of former Nazi concentration camps into historic sites. Michael Meng's Shattered Spaces examines how Jewish sites have evolved in post-war Germany and Poland. Meng states that "ruins... are hardly static; they have histories that change as people perceive and deal with them in different waysneglecting, destroying, altering, transforming, preserving, restoring, and reusing them." ${ }^{, 9}$ Meng focused on a variety of cities from both Germany and Poland, but did not examine Kraków or more specifically, Płaszów. Jennifer Jordan’s Structures of Memory focuses on memory and urban landscape of Berlin. In her work, she defines four factors that influence this relationship including "land use, landownership, the resonance of the site's meaning with a broader (often international) public, and the presence or absence of a 'memorial entrepreneur,' which is to say, someone willing to lobby on behalf of memorialization." 10 This thesis analyzes each of these aspects in relation to Poland's Płaszów site.

\footnotetext{
${ }^{6}$ Elinor J Brecher, Schindler's Legacy: True Stories of the List Survivors (New York, NY: Dutton, 1994$), 185$.

7 Ibid., 400.

${ }^{8}$ Ibid., 422-423.

${ }^{9}$ Michael Meng, Shattered Spaces: Encountering Jewish Ruins in Postwar Germany and Poland (Cambridge, MA: Harvard University Press, 2011), xxiii.

${ }^{10}$ Jennifer A. Jordan, Structures of Memory: Understanding Urban Change in Berlin and Beyond. Cultural Memory in the Present (Stanford, CA: Stanford University Press, 2006), 2.
} 
Sites such as Auschwitz and Majdanek have established memorial museums, regular employed site staff, and published guides from the site itself. Płaszów lacks such personnel and materials, allowing private tour guides or standalone visitors to draw their own interpretations and create their own narratives about the site. The Museum of Kraków has recently taken an interest in commemorating the site and held a conference in 2016, which resulted in the museum’s publication Discovering Płaszów.

Scholars have also written on cultural landscapes. Andrew Charlesworth has written two such articles related to Płaszów. In the first, "Memorialization and the Ecological Landscapes of Holocaust Sites: The Cases of Płaszów and Auschwitz-Birkenau," he discusses these two sites in relation to the physical landscape. While he included some historical context, his main focus remained on the "ecological management" of each site and its impact on the visitors. ${ }^{11}$ In his second article, "A Corner of a Foreign Field That Is Forever Spielberg's," Charlesworth included three different visitor perspectives during the years 1993 and 1996. Because of their close proximity in time to the filming of Spielberg's Schindler's List, these visitors' accounts provide an insight into the film's impact on the landscape. ${ }^{12}$

Another article “Geographies of Memory, Place, and Identity” by Danielle Drozdzewski and two collaborators explored "how memory traces are acknowledged, preserved, occluded, forgotten, and/or negated in both people and place."13 The authors reviewed a compilation of works and brought together different concepts of how landscape and memory are related. Drozdzewski discussed her recent work on post-war landscapes, and noted that "material

\footnotetext{
${ }^{11}$ Andrew Charlesworth and Michael Addis, "Memorialization and the Ecological Landscapes of Holocaust Sites: The Cases of Płaszów and Auschwitz-Birkenau," Landscape Research 27, no. 3 (2002): 229.

${ }^{12}$ Andrew Charlesworth, "A Corner of a Foreign Field That Is Forever Spielberg's: Understanding the Moral Landscapes of the Site of the Former Kl Plaszów, Kraków, Poland," Cultural Geographies 11, no. 3 (2004): 291312.

${ }^{13}$ Danielle Drozdzewski, Sarah De Nardi, and Emma Waterton, "Geographies of Memory, Place and Identity: Intersections in Remembering War and Conflict," Geography Compass 10, no. 11 (2016): 447.
} 
markers and the intangible memories of place" are significant for the national narratives of these European countries. ${ }^{14}$ Sather-Wagstaff's term "heritage that hurts" is also discussed, as she related it to the landscapes of the attacks of 9/11. Drozdzewski concluded that it is "through visitation to commemorative sites that some of the most powerful physical and emotional engagement with the visual and material culture of tragic event occurs." 15

Roma Sendyka's "Sites That Haunt: Affects and Non-Sites of Memory" described Płaszów as a site that "isn’t quite right" according to its visitors. Sendyka uses the phrase "nonsites of memory" which she defined as "abandoned, neglected locations, which nevertheless retain the right to commemoration" yet "generate a particular kind of affective aura that eventually becomes their trademark."16 This term is fitting for Płaszów because of the site's landscape, the lack of attention to the actual site of the former concentration camp, and the use of Spielberg film's location by the local tourist industry.

David Smith's Moral Geographies explains the shift in the 1980s to study landscapes in their own right, much like any other primary source. Landscapes, according to Smith, are "reflections of economic, political, and social systems, with their prevailing ideologies or "moral order' symbolized at the scale of settlement design and individual structure."17 This analysis can be applied to Płaszów by examining the subsequently human-shaped landscape of built structures, monuments, and plaques.

James Young's At Memory's Edge includes Jewish-American artist Shimon Attie's art exhibit that was displayed in Kraków in June and July of 1995. While his original plan was to

\footnotetext{
${ }^{14}$ Ibid., 452.

${ }^{15}$ Ibid., 451.

${ }^{16}$ Roma Sendyka, "Sites That Haunt: Affects and Non-Sites of Memory," East European Politics \& Societies and Cultures 30, no. 4 (2016): 688.

${ }^{17}$ David M. Smith, Moral Geographies: Ethics in a World of Difference (Edinburgh: Edinburgh University Press, 2000), 47.
} 
project historic images of the ghetto over the contemporary site and its structures, Attie changed his design after discovering Retracing “Schindler's List.” Instead of critiquing wartime memory, his new project became a critique of the "fascination for the filmic at the expense of the historical" and "displacement of historical by cinematic reality." Attie titled the exhibit "Walk of Fame," as he placed twenty-four stars resembling Hollywood Boulevard's "Walk of Fame" on Szeroka Street, the area Spielberg used as a film set for the ghetto. Within the stars were names from Schindler's list, Jews who had been saved by employment in his factory. Young summarizes, "By remembering victims as if they were worth remembering solely because they had now become Hollywood stars, Attie parodically repeated this flow of history into celebrity, mocking it and thereby hoping to expose its insidiousness." 18 This exhibit is one example of people recognizing the dangers of mixing the historical context with Spielberg's Hollywood scenes and calls attention to the possible public confusion regarding the site.

Historian Harold Marcuse examined former Nazi concentration camps and classified them into five categories according to their post-war use. His first category was education and it occurred almost immediately after liberation. In some cases, liberating troops forced local populations to tour the camp remains so they could be presented with material evidence of the Nazi regime's crimes. His second and third categories relate to those who remained at the camp after liberation. The Allied Powers used the camps to rehabilitate survivors or imprison Germans until their trials. The fourth category focused on actively preserving elements of the site for commemoration and future education. The fifth and final category Marcuse uses is the abandonment or ignorance of the site. ${ }^{19}$ Płaszów fell into this final category until the mid-1990s,

\footnotetext{
${ }^{18}$ James Edward Young, At Memory's Edge: After-Images of the Holocaust in Contemporary Art and Architecture (New Haven: Yale University Press, 2000), 85-89.

${ }^{19}$ Harold Marcuse, "The Afterlife of the Camps," in Concentration Camps in Nazi Germany: The New Histories, ed. Jane Caplan and Nikolaus Wachsmann (New York: Routledge, 2010), 186-187.
} 
when it became a popular tourist destination in Krakow due to the popularity of Schindler's List film. The postwar history of Płaszów has evolved over the years. After it was liberated by the Red Army in 1944, the site was largely ignored and overgrown with weeds and shrubs. The international success of Steven Spielberg's Schindler's List film provided an opportunity for Płaszów to become recognized by tourists and the local population.

Jennifer Jordan in her discussion of the relationship between memory and urban landscape in Berlin, defines four key factors which influence this relationship, including "land use, landownership, the resonance of the site's meaning with broader (often international) public, and the presence or absence of a 'memorial entrepreneur,' which is to say, someone willing to lobby on behalf of memorialization." ${ }^{20}$ In Jordan's examples, this individual or group was often someone with personal connections to the site, for example a witness or someone closely associated with the space.

Płaszów has had a very different type of memorial entrepreneur: Steven Spielberg. When Spielberg produced and directed his film Schindler's List, he drew international attention to Poland's landscape and heavily influenced Krakow's tourism industry. His decision to include scenes of the Płaszów camp and film near the location launched Płaszów from a site of forgotten memory to its present status as a preserved landmark and popular tour stop.

The film went on to make hundreds of millions of dollars at the box office and win seven Oscars, but its effect on Poland's landscape is also worth considering. Schindler's List has had a direct impact on the locations featured in the storyline. The film placed the former concentration camp Płaszów on the map for an international audience, allowed the opportunity for some to

\footnotetext{
${ }^{20}$ Jordan, 2.
} 
discover their family ties to the site's dark past, and led more people to rally for its preservation and interpretation.

\section{Organization}

The first chapter details the history of Spielberg's making of Schindler's List. By casting attention on Płaszów, his film put the site in public memory across the globe. Additionally, leaving parts of the set behind left a mark on the landscape. By examining the increasing number of movie-tours that were advertised in American newspapers and the quantity of guidebooks for Płaszów, the film drastically changed tourism for the city of Kraków.

The second chapter explores the opportunity the film and the physical site allow for individuals to explore their past. The impact of family heritage is one focus of this chapter. Monika Hertwig and Jennifer Teege discovered their familial connection to the camp commandant Amon Goeth and developed a unique relationship with the film and the site as a result. Survivors also were affected by the film. This thesis also focuses on three survivors active in the preservation of Płaszów’s memory.

The third chapter examines on the lasting impact of the film today. While movie tourism increased and thrived in Kraków, the lack of interpretation for Płaszów concentration camp remained an issue until recent years. The city of Kraków began managing the site as one of its branches in 2005 and the Museum of the City of Kraków became a partner in 2016. They have continued to extend educational programming for the site, such as workshops, lessons and guided tours. ${ }^{21}$ The visitors can be divided into those coming to pay their respects for the victims at a site of a former concentration camp and those who continue to use the site as a green space for outdoor activities.

\footnotetext{
${ }^{21}$ Kamil Karski (The Historical Museum of the City of Krakow), email to author, February 11, 2020.
} 


\section{Chapter 1}

\section{Spielberg Presents Plaszów to the World}

"In a shiny, German-built minivan, on a sparkling clear day last summer, we drove down a road in Crakow, Poland, paved with Jewish gravestones. The stones were fake - and I knew it: just concrete casts of real tombstones, they led into a fenced enclosure of crumbling barracks and rusting barbed wire that were also, I knew simply stage sets." 22

Travel and tourism researcher Dr. Sue Beeton described the term "film-induced tourism" as "visitation to sites where movies and TV programmes have been filmed as well as to tours to production studios, including film-related theme parks." Beeton also listed the different forms of this tourism, such as on-location, commercial, mistaken identities, and off-location. ${ }^{23}$ The Płaszów site falls under the on-location category and further can be classified as film tourism pilgrimage. This is described as "visiting sites of films in order to 'pay homage' to the film; possible re-enactments." Beeton uses Lord of the Rings, which draws international tourists to New Zealand, as an example. Similarly, Spielberg's Oscar-winner draws attention to Kraków. Dark tourism and Holocaust tourism, both related to the historical context of the former concentration camp, may also play a role, but the site itself was largely unknown until Spielberg's involvement, therefore making the film the most important factor when considering tourism. By examining advertised tours and guidebooks published after the film, one can see the impact that Spielberg's film has had on Płaszów.

Schindler's List propelled the city of Kraków from a post-war and former communist city into an international tourist destination. While increasing tourism was not Spielberg's intention,

\footnotetext{
${ }^{22}$ Ruth Ellen Gruber, "Remembering Poland's Jews.” The New York Times, January 29, 1995. Accessed January 10, 2020. https://www.nytimes.com/1995/01/29/travel/remembering-poland-s-jews.html.

${ }^{23}$ Sue Beeton, "Film-Induced Tourism," Aspects of Tourism, 25 (Clevedon: Channel View Publications, 2005), 1011, https://ebookcentral.proquest.com/lib/wvu/detail.action?docID=235048
} 
his film's impact on the city was immediate and transformed how some of the sites were viewed. The former concentration camp Płaszów was one of the key places affected. Left ignored for years, the site did not attract the attention of tourists like its proximate neighbors Auschwitz or Birkenau. From the time of filming to the film's release, international attention was on the site of the former camp.

The inspiration for Spielberg's film originated in a best-selling book by Thomas Keneally. In 1981, Keneally had met Holocaust survivor Leopold "Poldek" Pfefferberg and upon learning Keneally was a writer, Poldek insisted he had a story that needed published. Poldek had been imprisoned at Płaszów during the Holocaust but was saved by the actions of Nazi businessman Oskar Schindler. ${ }^{24}$ This account was published in October of 1982, and it continually sold out. Its film adaption would come more than ten years later.

Keneally and Poldek met Spielberg for the first time in December of 1982. In addition to inviting himself to the meeting, Poldek continually exclaimed, "You'll get an Oscar for Oskar!" to Spielberg. A few months later, Keneally received a call and immediately took a trip from his home in Australia back to California for two days in order to sign a contract with Universal. Poldek commented, "It means they must want to make the film straightaway," and Keneally agreed. ${ }^{25}$ This was not the case, however. The task of writing the screenplay would defeat three writers, including the original author. Keneally worked on it until the spring of 1985, when Spielberg brought Kurt Luedtke into the project. Keneally's writing had lacked a concise storyline and Luedtke also struggled with the narrative. Rumors circulated that Luedtke was too overwhelmed with research to complete a draft. By 1991, Steve Zaillian was working on the

\footnotetext{
${ }^{24}$ See Chapter 1 of Thomas Keneally, Searching for Schindler (New York: Nan A. Talese, 2007) for Keneally's account of their encounter.

${ }^{25}$ Keneally, 183-190.
} 
screenplay. ${ }^{26}$ In addition to struggling with the screenplay, Spielberg questioned his own involvement. He tried to pass off the project to Roman Polanski, a Holocaust survivor who lived in the Kraków ghetto before going into hiding. Polanski turned down Spielberg's offer because he did not want to experience the trauma again. ${ }^{27}$ As Spielberg hesitated, Universal gave the project to Martin Scorsese, who was the one to hire its final writer Steven Zaillian. Spielberg was supposed to make Cape Fear during this time until he decided he wanted the Schindler project. According to one of the film's producers, Scorsese did not want to give it up, so it resulted in a trade where Scorsese got Cape Fear instead. ${ }^{28}$

Spielberg was known for using his imagination to bring film projects into production, but for this one he struggled. "I couldn’t imagine the Holocaust until I went to Kraków, and to Auschwitz-Birkenau for the first time." ${ }^{29}$ He needed to see the landscape of the original sites before he was able to imagine filming Schindler's List. In an interview with Franciszek Palowski, the Polish journalist who served as a consultant and interpreter to Spielberg, the director said "Every time I turn a corner I say, 'Could Schindler have walked down this street? Was Amon Goeth around that corner? Is this where he drove his car when he divided the ghetto into ghetto A and ghetto B? Did he stand here when he sent people from the ghetto to labor and extermination camps?"'30 The power of place was important for Spielberg. The historic city of Kraków had escaped most of the destruction from the Second World War and was recognized by UNESCO in 1978 for its significance as a universally important historic city. ${ }^{31}$

\footnotetext{
${ }^{26}$ Ibid., 196-201.

${ }^{27}$ Joseph McBride, Steven Spielberg: A Biography 2nd ed. (Jackson: University Press of Mississippi, 2010 ), 426.

${ }^{28}$ Shoah Foundation, Testimony: The Legacy of Schindler's List and the USC Shoah Foundation. 1st ed. (New York: Newmarket, 2014), 10.

${ }^{29}$ Ibid.

${ }^{30}$ Franciszek Palowski, The Making of Schindler's List: Behind the Scenes of an Epic Film, trans. Anna \& Robert G. Ware (Secaucus, N.J.: Carol Pub. Group, 1998), 174.

${ }^{31}$ Shoah Foundation, 36.
} 
When it came time to plan for filming, Spielberg approached Thomas Keneally, wondering if the film could potentially be shot in Kraków. ${ }^{32}$ Keneally had traveled to the city in 1981 to conduct research for his book Schindler's List, also published as Schindler's Ark. Płaszów was one of the places that survivor Leopold "Poldek" Pfefferberg showed Keneally during the trip. Keneally remembered, "I took photographs of everything, but they were not necessary. I can still bring to mind the camp plan, the green bed of the fort where the brave and adventurous died... The geography is still engraved on my brain by the force of the events I heard of there." ${ }^{33}$

Visiting the site of the former camp remained in Keneally's mind because he had heard first-hand accounts of the horrors that occurred on the now-vacant field. If Keneally had not been accompanied by Poldek, his experience may have been quite different. Płaszów’s site had been left vacant. Unlike Auschwitz and Majdanek, there were few things left of the original camp. The two remaining structures included the Grey House and commandant Goeth's villa. This site did not follow the path of Auschwitz and Majdanek, with their post-war preservation status, additions of an educational museum and staff, and public exhibits that opened as early as $1945 .{ }^{34}$ While these exhibits still had their own issues, notably relative neglect of Jewish victims in their emphasis on Poland victimhood, the sites did supply interpretation for public consumption. Płaszów did not have any of this. The site was marked by one large monument and resembled more of a public park than memorial ground.

The Germans had started the process of destroying evidence at Płaszów in August and September of 1944. During this time a group of Jews was ordered to dig up the mass graves and

\footnotetext{
${ }^{32}$ Keneally, 209.

${ }^{33}$ Ibid., 115-116.

${ }^{34}$ Marcuse, 192.
} 
cremate the bodies. The process extended into mid-October. Plans to evacuate the camp began in the summer of 1944 as the Red Army advanced westward. The final evacuation order was given on January 14, 1945 to take the remaining inmates to Auschwitz. By the time the Red Army reached Płaszów, it was January 17 and little remained of the camp. ${ }^{35}$ Most buildings were taken down by the camp's inmates, but the few remaining structures were "devastated" by the Red Army's occupation or by local people tearing them down. ${ }^{36}$ Wood from the barracks was most likely used for firewood. In an August 1954 letter to the Ministry of Culture and Art, it was noted that "barracks and all equipment of the labor camp in Płaszów had disappeared."37

Filming on-location would prove to be problematic. Płaszów’s original site was surrounded by a modern day city and featured a few monuments. The largest, the Monument of the Victims of Fascism, was dedicated on September 3, $1964 .{ }^{38}$ It was designed by Ryszard Szczypczyński and Witold Ceckiewicz and features five connected figures with their heads down and a crack running through them. ${ }^{39}$ The project was a result of several groups coming together, including the Social Fund of the Reconstruction of the Capital, the Council for the Protection of the Struggle and Martyrdom, the Presidium of the City of Kraków National Council, and the Socio-Cultural Society of Jews in Poland. ${ }^{40}$ Spielberg noticed these obstacles during his initial trip in early 1992 and decided to reconstruct the camp off-site at the Liban chalk quarry. ${ }^{41}$

\footnotetext{
${ }^{35}$ Geoffrey P. Megargee, ed. Encyclopedia of Camps and Ghettos, 1933-1945. Vol. 1. Part B (Bloomington, IN: Indiana University Press \& the United States Holocaust Memorial Museum, 2009), 865.

${ }^{36}$ Marta Śmietana and Monika Bednarek, ed. Discovering Płaszów, Kraków, Poland, April 15-16, 2016. (Kraków, Poland: Historical Museum of the City of Kraków 2019), 100.

${ }^{37}$ Ibid., 110.

${ }^{38}$ Ibid., 119.

${ }^{39}$ James Edward Young, The Texture of Memory: Holocaust Memorials and Meaning, Mazal Holocaust Collection (New Haven: Yale University Press, 1993), 193.

${ }^{40}$ Śmietana and Bednarek, 121.

${ }^{41}$ Keneally, 211.
} 
There would later be controversy surrounding filming at the Auschwitz concentration camp. Certain groups feared it would affect the authenticity of the site and there were concerns of Spielberg building a film set of gas chambers on the property. Spielberg had received permission from the Polish government to film at the Auschwitz site, but in January the vice president of the World Jewish Congress Kalman Sultanik spoke out against this publicly in the New York Times and claimed the organization had not been consulted. This proved to be a matter of miscommunication. Four months earlier, Spielberg had received permission from the group via a signed letter from its director, E. Steinberg. The rumor of building a film set of gas chambers on the property was also false, but neither the letter nor reassurance that they were not building such a set calmed Sultanik. Instead, he turned to the International Council of the State Museum in Auschwitz. They consulted for two days before returning with the decision that Spielberg could film at the site but with limitations. They were concerned because the film was a story-telling narrative as opposed to documentary-style filming that had previously used the site. As a result, filming on the site would be limited to documentary-style shots and no extras or sets were to be constructed there. Instead, six barracks were moved from the reconstructed set of Płaszów and rebuilt outside the site, in front of the entrance to Auschwitz Birkenau. ${ }^{42}$

This controversy sparked the attention of multiple groups with opinions on both sides of the issue. Most supported Spielberg and his efforts to advance Holocaust education through one of his films, but they differed in how the filming should take place. The Simon Wiesenthal Center's Rabbi Marvin Hier remarked that "to put so many restrictions on him will only give credit to Holocaust revisionists" and described the attempt to stop filming at the site as "really an insult." The project director of the United States Holocaust Museum, Michael Berenbaum, had

\footnotetext{
${ }^{42}$ Palowski, The Making of Schindler's List, 59-61.
} 
no objections to the film itself, but supported filming at a nearby location as opposed to inside the site itself. The Anti-Defamation League's David Lehrer commented that new digital technologies could potentially replace filming at an actual site, but also that Spielberg's reputation should be considered and the director given some leeway. ${ }^{43}$ This debate did not affect the filming of the Płaszów scenes because Spielberg had already decided a reconstruction was necessary. However, it does emphasize the amount of public attention on Spielberg's project even during the early stages of filming. The project interested people due to its content and association with Spielberg.

Płaszów’s landscape today is similar to how it appeared to Spielberg in the mid-1990s. Modern-day buildings encroached the property from most angles and the large memorial monument was visible from most of the landscape. The only existing structures at the site were the Grey House, which was used for punishment by the SS, and Goeth's villa, sometimes referred to as the Red House. Neither of the original structures were used during filming.

Spielberg assessed the property and decided to reconstruct the replica in the nearby Liban Quarry. Allan Starski, a native of Poland and the film's production designer explained, "We built Płaszów to be as realistic as possible. We put stables and a garage, Goeth’s villa, the main gate and everything else. Spielberg could shoot from any angle, from any corner, and all you could see is the camp. It's built with so much accuracy that it was like coming into the real thing." 44 The replica cost Spielberg around $\$ 600,000$ and included 34 barracks and 11 watchtowers. ${ }^{45}$

\footnotetext{
${ }^{43}$ Tom Tugend, "WJC Fights Filming at Auschwitz, but Other Groups Less Concerned." The Daily Bulletin, January 22, 1993. Accessed February 3, 2020. https://www.jta.org/1993/01/22/archive/wjc-fights-filming-atauschwitz-but-other-groups-less-concerned.

${ }^{44}$ Shoah Foundation, 45.

${ }^{45}$ Jack Schnedler, “The Scenes of the Crime," St. Petersburg Times, October 9, 1994: 5E. NewsBank: America's News. https://infoweb.newsbank.com/apps/news/documentview? $\mathrm{p}=$ NewsBank\&docref=news/0EB52D0B127A3A35.
} 
Increased foot traffic to the site occurred simultaneously with filming. Almost three hundred people from media outlets wanted to come to Kraków to tour the sets and conducts interviews. Spielberg was known for his dislike of media presence on set, and he had not allowed any on the Jurassic Park set. For Schindler's List, he allowed only a few journalists including those from the New York Times, Life, Newsweek, the Los Angeles Times, Poland's Gazeta Wyborcza and Rzeczpospolita, and a few from Israel and Australia. ${ }^{46}$ Franciszek Palowski claimed, "Kraków is becoming a town where Hollywood celebrities drop in for the weekend." This included George Lucas, Sidney J. Sheinberg, the head of Universal Pictures, and Tom Pollack, the company's head of film production. ${ }^{47}$ Lew Rywin, one of the film's producers, asked Palowski to represent them and give visitors an overview of the book and upcoming film. Palowski met with a group of Israeli high schoolers the day before Spielberg started filming. They had already visited the Płaszów site and heard of Oskar Schindler's actions. One Polish woman, Ziuta Grünberg, approached Palowski afterwards. Grünberg was not part of the school group, but she joined it because she was prisoner at the Płaszów concentration camp. She was held hostage with her mother by Goeth as collateral while her father was ordered to build a guardhouse for SS officers. She was also one of the prisoners ordered to dismantle the camp as the Red Army approached and was then sent to Auschwitz three days before Płaszów's liberation. ${ }^{48}$ Grünberg is just one example of the many survivors who were curiously watching Spielberg's work at the time.

Spielberg's time spent in Kraków may have been short, but it had a lasting impact. He and his family arrived on the morning of February 24, 1993 to get settled into their temporary

\footnotetext{
${ }^{46}$ Palowski, 165.

${ }^{47}$ Ibid., 135.

${ }^{48}$ Ibid., 70.
} 
home on Zielony Dół Street. ${ }^{49}$ Filming began on March 1 and continued until Spielberg called, "Wrap!" on May 26 around 2 am. ${ }^{50}$ The following day the film crew, cast, and survivors flew to Jerusalem to film the final scene at Oskar Schindler's gravesite. ${ }^{51}$ The movie premiered first in Washington, D.C. on November 26, 1993 with author Thomas Keneally in attendance. ${ }^{52}$ The film then premiered in the United States in December 1993 and in Germany on March 1, 1994. ${ }^{53}$ Spielberg had spent three months using Kraków's landscape as a film set and in return the city would expand its role as a tourist attraction in Poland.

Spielberg's film immediately drew crowds to Kraków. The tourism business started with one local bookshop and shortly afterwards private tour companies were formed. International tours also developed and largely were marketed towards Americans. According to Zdzislaw Les, people began coming to the city before the film's release. Les, owner of the Jarden Jewish Book Shop, organized the first movie tour in either December 1993 or January 1994 when New York tourists came to his shop looking for the main gate of Płaszów. They showed him an article from the New York Times and Les realized they did not understand that "this gate is papier mache, made for the movie." ${ }^{54}$ When Les noticed the increasing demand for information about sites related to Schindler's List, he hired Franciszek Palowski, who had served Spielberg's team as a translator and consultant, to create a guidebook. ${ }^{55}$ The result was a twenty-page book titled, Retracing "Schindler's List.” The guidebook only had four pages of textual information, but

\footnotetext{
49 Ibid., 44.

${ }^{50}$ Ibid., 148.

${ }^{51}$ Ibid., 151.

52 Thomas Keneally, Searching for Schindler (New York: Nan A. Talese, 2007), 248-249.

53 Yosefa Loshitzky, Spielberg's Holocaust: Critical Perspectives on Schindler's List (Bloomington: Indiana University Press, 1997), 18, 171.

${ }^{54}$ Elizabeth Williamson, "Schindler's Tour Is a Moving Lesson: Movie Draws Tourists to Polish Sites," The Wall Street Journal, August 27, 2020, accessed January 10, 2020, https://www.wsj.com/articles/SB935766557585799207.

${ }^{55}$ Erica T Lehrer, Jewish Poland Revisited: Heritage Tourism in Unquiet Places (Bloomington, IN: Indiana University Press, 2013), 32.
} 
appeared in three languages, Polish, English, and German. ${ }^{56}$ By December of the first year, about 1,000 people had taken the original tour organized by the Jarden bookshop. The tour had seven stops, balancing film sets and historical sites. These sites included Schindler's factory and the historic site and film sites for the ghetto and Płaszów. ${ }^{57}$ Les's shop sold Retracing "Schindler's List" for about a dollar to tourists who wanted to see the sites on their own. ${ }^{58}$

By May 1994, Les commented, “There are about five times as many people coming here than at this time last year. And more or less all of them know the place from 'Schindler's List." ${ }^{, 59}$ In 1999, the bookshop offered four different tours, including the two-hour Schindler's List Guided Tour priced at 40 zlotys per person, or roughly ten dollars. According to Les, his tour is primarily booked by American and Israeli tourists but people from the U.K., Holland, Germany and Scandinavian countries have also participated. In response to commercial tours which popped up and copied his tour and its posters, Les asserted, "But ours is the most authentic." ${ }^{60}$ In addition to the bookshop's tours and guidebook, sites related to Spielberg's filming locations were advertised in Kraków's monthly tourism guide "What, Where, When" by the fall of 1994. Two of the sites included were "'Jews forced to shovel snow' scene and 'little girl in the red coat' scene" locations from the film. While the city did not have a tour of its own, the state-run Orbis tourist agency carried these publications. ${ }^{61}$

\footnotetext{
${ }^{56}$ Franciszek Palowski, Retracing “Schindler’s List,” (Kraków: Argona Jarden), 1994.

${ }^{57}$ Dan Fesperman, “'Schindler's List' Tour Stops at Real and Movie Sites," Sun-Sentinel, December 25, 1994 : 8J. NewsBank: America's News. https://infoweb.newsbank.com/apps/news/documentview? $\mathrm{p}=$ NewsBank\&docref=news/0EB4EE5EF3EEC370.

${ }^{58}$ Gruber, "Remembering Poland's Jews."

${ }^{59}$ Julian Borger, "'Schindler's List' Draws Tourists to Kraków," Scripps Howard News Service, May 18, 1994. NewsBank: America's News. https://infoweb.newsbank.com/apps/news/documentview? $\mathrm{p}=$ NewsBank\&docref=news/0EB7AF2BE4C3DD37.

${ }^{60}$ Williamson, "Schindler's Tour Is a Moving Lesson: Movie Draws Tourists to Polish Sites."

${ }^{61}$ Fesperman, "'Schindler's List' Tour Stops at Real and Movie Sites."
} 
American newspapers played a key role in increasing tourism to the site. It was not uncommon for articles to include a description of Spielberg filming in the city, followed by travel information such as hotel accommodations and tour guide prices. While the Jarden bookshop may have had the original tour, it did not take long for private companies to begin advertising.

Stu Feiler, a journalist in Chicago, was inspired by Schindler's List. He had lost thirty family members during the Holocaust and decided to develop an international tour, departing from Chicago and touring “Oskar Schindler's Poland.” Feiler was assisted by Marta Wegrzyn, a former Kraków guide, Marcel Ofiarski, director of Poland's national tourism office in Chicago, and Edward Turkiewicz, head of a Polish tour company. ${ }^{62}$ Turkiewicz commented, "What 'Out of Africa' did for Africa, and 'Amadeus' did for Prague, so 'Schindler's List' could do for Kraków."63

Feiler planned for his 11-day tours traveling around Kraków to see sites portrayed in the film. For around \$1,500 visitors would experience "the historic Jewish district, synagogues, and cemetery...Auschwitz-Birkenau concentration and extermination camp; Tarnow, site of a World War II ghetto; Rzeszow, with its New Town synagogue dating to the seventeenth century; Lancut, site of a nineteenth century Jewish cemetery with a memorial to Holocaust victims; Schindler's Factory, and Plaszow, the concentration camp that held Schindler's Jews." Feiler

\footnotetext{
62 Jack Schnedler, "Chicagoan Creates Tours of `Oskar Schindler's Poland'." Chicago Sun-Times, April 3, 1994:

2. NewsBank: America's News. https://infoweb.newsbank.com/apps/news/documentview? $\mathrm{p}=$ NewsBank\&docref=news/0EB421AD6350C82A.

${ }^{63}$ Borger, "'Schindler's List' Draws Tourists to Kraków."
} 
planned to schedule a tour every three weeks. ${ }^{64}$ The first tour, departing on June 15 , was advertised in newspapers with the headline "Travelers can Visit Schindler's Poland". ${ }^{65}$

Jack Schnedler, travel editor for the Chicago Sun-Times recounted his experience on the tour in August 1994. During one of the first days, Feiler arranged for Franciszek Palowski to take the group around areas used for the film. He recalled viewing three Jewish-themed cafes as well as the bookshop advertising tours of Schindler's List locations in the window. Schnedler noted “it was an eye-opening surprise to discover that Poland's Jewish heritage has become a highly marketable commodity here, notwithstanding the virtual absence of flesh-and-blood Jews." ${ }^{66}$ As early as the summer of 1994, people noticed the oddity of this film-induced tourism that locals were promoting in Kraków.

Some did not ignore the danger of combining historical fact and the film set's fiction. One news article noted, "'Schindler tourism' may have come just in time to save the district's crumbling buildings from terminal decay, but in return Kazimierz has had to swallow some pride and sell itself as a recently used film set. When it comes to attracting the crowds, six centuries of history count as little compared to a couple of hours of screen fame." ${ }^{67}$ Spielberg had immortalized Kraków's Jewish district and brought the city international recognition, prompting an increase of tourists. The increase of these tourists also brought an increase in confusion regarding location. The location of the film's set often deviated from the location of historical events, such as the Płaszów camp.

\footnotetext{
${ }^{64}$ Schnedler, "Chicagoan Creates Tours of `Oskar Schindler's Poland'."

65 "Travelers Can Visit Schindler's Poland." Greensboro News \& Record, June 5, 1994: D3. NewsBank: America's News. https://infoweb.newsbank.com/apps/news/documentview? $\mathrm{p}=$ NewsBank\&docref=news/0EAF85A1D6ECBA97.

${ }^{66}$ Jack Schnedler, 'Destination Poland: The Schindler's List Tour: A journey, inspired by Spielberg's Holocaust film, through the remnants of Jewish life in Poland," Los Angeles Times, August 21, 1994. Accessed January 10, 2020. https://www.latimes.com/archives/la-xpm-1994-08-21-tr-29725-story.html.

${ }^{67}$ Borger, "'Schindler's List' Draws Tourists to Kraków."
} 
When Spielberg left Kraków in May 1994, his film set was still standing in the Liban quarry. For a brief period, local tours used both the film set and historical site of the former Płaszów concentration camp. One tourist, Ruth Ellen Gruber, recounted her experience through the private tour company Jordan Tours in the summer of 1994. She recalled driving down the "200-yard long road of concrete tombstones... [and] the fencing and barracks with fake tile roofs made out of now-tattered plastic." 68 The set in its entirety did not last long, much to local businesses' dismay. A July 1994 news article stated, “The Kraków city administration, showing tremendous lack of foresight, has knocked down most of Spielberg's set, but a portion of it remains in place." ${ }^{99}$ In an October article, Palowski was quoted saying, "They're already torn down almost all the 34 barracks and 11 watchtowers built for the movie... It's a shame. The set might have been a worthwhile attraction." 70

In addition to planned tours, guidebooks also became popular for the site. By examining guidebooks, one can see how the attention on Płaszów increased after Spielberg’s film. Before Spielberg’s film, few guidebooks on Kraków mentioned the concentration camp. One publication from 1992, Hippocrene Insiders' Guide to Poland's Jewish Heritage, had over two hundred pages on important historic events, sites, and figures. In regard to Płaszów, the book included only six sentences: "The concentration camp near Crakow was established in December 1942 on the territory of the Jewish cemetery. This was the last camp established in Poland. One hundred fifty thousand people passed through the camp during its existence. Some eighty thousand people lost their lives there. The camp was liquidated in the fall of 1944. The

\footnotetext{
${ }^{68}$ Gruber, "Remembering Poland's Jews."

${ }^{69}$ John Conroy, "Tours of Holocaust sites available," Daily Breeze (Torrance, CA), July 24, 1994: F2. NewsBank: America's News. https://infoweb.newsbank.com/apps/news/documentview? $\mathrm{p}=$ NewsBank\&docref=news/1125C6EB813AE930.

${ }^{70}$ Schnedler, "The Scenes of the Crime."
} 
monument on the premises of the former concentration camp in Płaszów near Crakow was designed by Ryszard Szczypczynski and Witold Ceckiewicz."71 This guide's limited information did not provide visitors with any additional travel accommodations or visitor information. Płaszów was treated much differently from other sites. Sites like Gross-Rosen, another concentration camp, were given almost two pages and included camp illustrations and maps. Auschwitz had nine pages dedicated to its site and included 3 maps and timelines of significant events. ${ }^{72}$ Płaszów was not commonly known, especially by international visitors, until Spielberg's project brought it to their attention.

The first guidebooks featuring the film emerged within a year of its release. After the film production wrapped up, Zdzislaw Les of Jarden Book Shop hired Polish journalist and Spielberg's consultant Franciszek Palowski to create a tour guidebook based on the movie's filming locations and historic sites. ${ }^{73}$ Retracing 'Schindler's List' was published in 1994, shortly after the film's release. While the information is short and limited, the text only spanning four pages, the single guide included three translations, Polish, English, and German. ${ }^{74}$ Many other publications followed. The Agencja Wydawnicza "Gestum” tourist company published "Schindler's List” A Guidebook: Extermination of Cracow Jews a couple of years after the film's release. Several editions were published with new information and advertisements for new tours. The third edition, published in 1998, had an advertisement on the first page for Jordan Travel Agency tours. It offered tour services to groups and individuals to several sites around town, including the Salt Mines in Wieliczka and the Museum at Auschwitz. It does not mention

\footnotetext{
${ }^{71}$ Joram Kagan, Hippocrene Insiders' Guide to Poland's Jewish Heritage (New York: Hippocrene Books, 1992), 108.

${ }^{72}$ Kagan, 44-52, 75.

${ }^{73}$ Erica T Lehrer, Jewish Poland Revisited: Heritage Tourism in Unquiet Places (Bloomington, IN: Indiana University Press, 2013), 32.

${ }^{74}$ Palowski, Retracing "Schindler's List."
} 
Płaszów or Spielberg's filming locations. Apart from this advertisement, both the third and fourth editions are identical. The fourth edition was published in 2001. Two advertisements at the end of each booklet are for the Ariel Café and Restaurant Gallery and the Point Tours and Travel Company. While Ariel promised traditional Jewish cuisine and daily Jewish music, the Point Tours and Travel company advertised tours specifically for "foreign tourists." The advertisement explained the company offered daily tours of Krakow including "Regular and special tours to Auschwitz-Birkenau... The traces of Jewish Culture in Krakow [and] Retracing 'Schindler's List."' Both editions follow the same format. There are about twenty-two pages of text, in both German and English, as well as images and maps. After the text, there is a five-page chronicle of significant events related to Nazi-occupied Krakow. ${ }^{75}$ Compared to the previous guide from 1992, which dedicated only six sentences to the site, this guide gave Płaszów eight pages of historical context. ${ }^{76}$

Local guidebooks increasing the amount of space allotted to Płaszów was not the only thing that changed after the film. It also was featured in other guidebooks that otherwise may have left it out. In 2002, Płaszów was included in The Rough Guide to Poland. While it was only given three short paragraphs, the comprehensive travel guide includes all major attractions of Poland, not just those that were specifically Jewish or historically significant. The three previous guidebooks were created to detail Poland's Jewish life or to respond to the influx of tourists asking about Schindler's List. Instead, The Rough Guide to Poland already existed as a publication, but it now chose to include the site among other historic sites and major attractions. According to The Rough Guide, "local guidebooks often fail to mention the site." 77 While the

\footnotetext{
${ }^{75}$ Krystyna Samsonowski, "Schindler's List” A Guidebook: Extermination of Cracow Jews, $4^{\text {th }}$ ed. (Poland: Agencja Wydawnicza "Gestum”, 2001), 31-32.

${ }^{76}$ Ibid., 18-25.

${ }^{77}$ Mark Salter and Jonathan Bousfield, The Rough Guide to Poland (Rough Guides, 2002), 445-446.
} 
site may seemingly have been ignored by residents, the international tourist community was eagerly interested.

A 2003 publication, Jewish Cracow: A guide to the Jewish historical buildings and monuments of Cracow, dedicated an entire chapter to Płaszów. The publication was marketed towards American and other English-speaking tourists, as the text is in English. Unlike the previous guides, it included both the historical and modern contexts of the site. Black and white archival images often are positioned beside present-day images of the site. While the guide did not mention Spielberg's film, it placed an emphasis on Schindler's effort to save Jews within the narrative. Amon Goeth's involvement at the camp and status of his villa were also noted. At the end of the section, the authors included information on the current memorials and remaining structures at the site. The memorial monuments with Polish and Hebrew text engravings were translated in the work for English speakers. ${ }^{78}$ By including this, Jewish Cracow became the guide with the most historical context and visitor information to that date.

In the same year, Marc Terrance published Concentration Camps: A Traveler's Guide to World War II Sites. As a frequent traveler to Holocaust-related sites, he realized he often struggled with directions. He decided to revisit "ALL of the major Holocaust sites" in the fall of 1998. Terrance "walked from the nearest train station to the camps, hand-drawing maps, jotting down landmarks and street names and gathering information from every source" to make it easier for future tourists to the site. ${ }^{79}$ His guide encompassed six countries: Poland, Germany, Austria, the Czech Republic and the Netherlands. Poland and Germany had the most sites, with eleven and twenty-one respectively. It is unclear why Terrance began his work with Poland, but

\footnotetext{
${ }^{78}$ Eugeniusz Duda, Jewish Cracow: A Guide to the Jewish Historical Buildings and Monuments of Cracow (Kraków: Vis-à-vis/ etiuda, 2003), 114-123.

${ }^{79}$ Marc Terrance, Concentration Camps: A Traveler's Guide to World War II Sites (Universal Publishers, 2003), 2.
} 
the first sites listed are Auschwitz-Birkenau, Schindler's Factory, and Płaszów. While this guide did not focus on historical context, it included information on travel options, the dates of operation, and remnants from the original site. Though Terrance claimed that "absolutely nothing remains of this camp," there were still some structures associated with it, such as the Grey House or Goeth's villa. ${ }^{80} \mathrm{He}$ also included his thoughts on the site and noted, "Litter and garbage is cluttered around. As a memorial It's a Disgrace." He continued, “NOTE: Of all the camps I've been to, this is one of the most neglected and hard to find sites. There are NO signs or markers leading the way to the monuments and there is garbage, broken bottles, and graffiti." ${ }^{\prime 1}$

Guidebooks in recent years have been dedicated specifically to this "neglected" site. Bernard Offen's 2008 guide My Hometown Concentration Camp: A Survivor's Account of Life in the Kraków Ghetto and Płaszów Concentration Camp provided a personal account and visitor information regarding Płaszów. Offen, a survivor who was imprisoned at the camp, first returned to Poland in 1981 and was a regular visitor to Kraków since $1991 .^{82}$ The book’s foreword explained, "What makes Bernard Offen's account unique is the way he intersperses his description of what was done to the Jews with his account of what one can see in the same places today, an account which draws heavily on his own experience guiding groups around the sites of suffering and martyrdom... his book [is] not only a moving testimony but an essential companion for those many tourists visiting Kraków today who want to relive the experience of its Jews during the Holocaust and who want to understand the wider experience. They can have no better guide than Bernard Offen." 83 Offen’s guide was almost entirely dedicated to the Płaszów site and combined historical information with its present-day context for visitors. Like an academic work,

\footnotetext{
${ }^{80}$ Ibid., 20-25.

${ }^{81}$ Ibid., 25.

${ }^{82}$ Offen and Jacobs, xviii.

${ }^{83}$ Ibid., xix.
} 
Offen included endnote citations, a timeline of significant events related to the ghetto and camp, tables to show the population of the sites over time, and a bibliography for readers. ${ }^{84}$

In 2014, Ryszard Kotarba released the most comprehensive guidebook for Płaszów. This guide included more than ninety pages on the former concentration camp. The first section, about sixty pages in length, provided historical context while the remaining portion detailed a "proposed visiting route" including maps, historical and contemporary images of the site, and a pull-out map. Kotarba did not refer to the Schindler's List film or the fact that there were set remains in the Liban Quarry. In fact, he almost ignored the existence of the Liban Quarry altogether. His report may easily confuse potential visitors to the site. He included the quarry as stop eighteen on his map and wrote, "Located at the junction of the SS-Strasse and the Bergstrasse and separated from 'The Grey House' by a big square, the quarry started to operate in 1943 for the rock and gravel which were needed for the construction of camp roads and facilities. The other quarry was located more north, near the barracks for Jewish women." This "other quarry" he referred to was the Liban Quarry, where Spielberg reconstructed his set. He continued, "In 1944, a penal company worked under truly emaciating conditions in this quarry. The prisoners fell victim to the Kapos who were German criminals. Today, the rock excavations are partially covered with vegetation, and the visible holes in the rock from air-raid shelters excavated by the prisoners. The quarry is also associated with the Manschaftszug, a narrowgauge railway used to transport stone and gravel. The train consisted of three little wagons propelled by several dozen female prisoners, who pulled a rope." 85

\footnotetext{
${ }^{84}$ Ibid., 118-133.

${ }^{85}$ Ryszard Kotarba, A Historical Guide to the German Camp in Płaszów 1942-1945, trans. by Kamil Budziarz and Dorota Plutecka (Poland: Institute of National Remembrance Commission of the Prosecution of Crimes against the Polish Nation, 2014), 85.
} 
Kotarba's work was the first of the guides to point out the existence of two quarries. Though Kotarba explained the camps border's clearly in his text, he mentioned the Liban Quarry, but not by name. Within the first pages he stated, "In the north, the camp bordered on the Municipal Limestone Quarry, in the south - Pańska Street along with the buildings; in the west Swoszowicka Street; and in the east - Wielicka Street." 86 The bordering quarry in the north was the Liban Quarry. This again was the limestone quarry where Spielberg reconstructed the camp using original blueprints. The quarry Kotarba included on his map was near the Grey House, at a significant distance from where Spielberg filmed.

The only other source that mentioned the existence of two quarries was Discovering Płaszów, the 2016 conference publication. In detailing the proposed development for the site as "Contemplation Park," it read, "The park was to be a part of the Podgórze Leisure Centre and was to serve the city and district's recreational function. In the quarry at Wielicka Street, the Centre of Arts was to be created, and it was to be supervised by the Workshop of Fine Arts. In the Liban quarry, bordering with the area of the park, it was planned to organize open-air swimming pools." ${ }^{87}$ While the content is not relevant, as the park's development did not occur, the mentioning of two quarries does align with Kotarba's text.

Kotarba's final pages are a large map of the camp with a key to label all nineteen of his suggested stops. He included the quarry as stop number eighteen and it is placed near the Grey House and Monument to the Victims of the Crime of September 10, 1939. There is no label for the Liban Quarry, which bordered the area of the camp.

In Andrew Rawson's Schindler's Krakow: The City Under the Nazis, Płaszów only receives one chapter. This 2015 guidebook was specifically crafted towards visitors looking for

\footnotetext{
86 Ibid., 16.

${ }^{87}$ Śmietana and Bednarek, Discovering Płaszów, 128.
} 
locations associated with Schindler, both historic and film-related. Rawson provided a concise overview of the historic significance of the camp, images of Amon Goeth and his villa, and a map. This map labels the women's camp and the men's camp as well as the Grey House and Goeth's villa. Only one quarry, the Liban Quarry, was labeled, and it was located north of the women's camp, outside of Płaszów's borders. ${ }^{88}$ Rawson's travel instructions included both information and a warning: "The scenes relating to Plaszow camp and Amon Goth were filmed there [in the Liban Quarry] and parts of the decaying film set can still be seen. A path does follow the edge of the quarry but do not try to go down." 89

The Historical Museum of the City of Kraków does not have a guidebook for Płaszów. The concentration camp was featured in their Oskar Schindler's Enamel Factory: Guidebook because the factory has an exhibit about the camp. The guidebook has a few short paragraphs with basic information on the camp but is not as extensive as Ryszard Kotarba's guide. ${ }^{90}$

Some local tour companies wanted to develop Płaszów as an attraction for their film tours. Newspapers advertised that the proceeds of Jarden Jewish bookshop's tour would be used to rebuild Spielberg's Płaszów set in the Liban quarry. ${ }^{91}$ It is unknown how popular this idea was among the residents. This reconstruction of a reconstruction did not occur, and the current remnants of the movie set have been overtaken by nature. The site of the Liban quarry was owned by the Kraków sanitation department in the summer of 1994. According to Gruber, "sanitation trucks actually did rumble over the trail of fake tombstones taking loads of rubble and building material to a sort of dump at its end, just as Nazi trucks had done on the real road of

\footnotetext{
${ }^{88}$ Andrew Rawson, Schindler's Krakow: The City Under the Nazis (Barnsley, South Yorkshire: Pen \& Sword Military, 2015), 93-106.

${ }^{89}$ Ibid., 131.

${ }^{90}$ Anna Marszałek, Monika Bednarek, Krystyna Stefaniak, and Piotr Krasnowolski, Oskar Schindler's Enamel Factory: Guidebook (Kraków: Muzeum Historyczne Miasta Krakowa, 2015), 36-37.

${ }^{91}$ Fesperman, "'Schindler's List' Tour Stops at Real and Movie Sites."
} 
tombstones half a century earlier." 92 It is unknown who officially manages the site today; however, many tourists have explored the site and recorded their findings on YouTube.

The blending of film sites and historic sites on tours, as well as the leftovers from Spielberg's set, have led to a confusion among visitors. Detailing her tour experience, Gruber recalled, "Our guide...stumbled into confusion as he attempted to separate our Hollywood and Holocaust experience... Each site was given equal weight." 93 For visitors to the site, the mix of film set and historical landscape is easily confusing. Private tour guides have the ability to educate their attendees regarding the confusing landscape, but this entirely depends on the knowledge of the guide. For individuals visiting the site on their own, they can easily misunderstand the site and interpret the movie set as the authentic, historical site.

By examining newspaper advertisements for film-tours and the increase in guidebooks including the site, one can see that the importance of Płaszów in Schindler's List led to an increase in tourism. Regardless of whether visitors took a walking tour from locals like the one by Zdzislaw Les's bookshop, an organized international trip like Stu Feiler's Chicago to Poland tours, or went to the site individually using a guidebook, the increase in all three types of visitation to the site should be credited to Steven Spielberg. Spielberg's renowned reputation as well as the film's content forged the path for Plaszow to reach international fame.

\footnotetext{
${ }^{92}$ Ruth Ellen Gruber, Virtually Jewish: Reinventing Jewish Culture in Europe, The S. Mark Taper Foundation Imprint in Jewish Studies (Berkeley: University of California Press, 2002), 128-129.

${ }^{93}$ Ibid., 128.
} 


\section{Chapter 2}

\section{Personal Relevance of the Site and Film to Individuals}

Schindler's List's widespread success brought the story of the Holocaust and life in Nazioccupied Poland to people around the world. Among audience members were witnesses to the Nazi regime's crimes, including survivors, bystanders, and soldiers of both Allied and Axis nations. With its release date in the mid-1990s, the film also attracted viewers from younger generations looking to gain an insight to the past. This chapter examines two sets of individuals affected by the Schindler's List film and Płaszów, the daughter and granddaughter of its head commandant featured in the film on one hand and a few survivors of the camp on the other. All these individuals felt a connection to the site of the former concentration camp Płaszów, often resulting in a pilgrimage back decades after its liberation.

For Monika Hertwig and Jennifer Teege, watching the film provided more than a reflection on the Nazi regime's crimes. Both Hertwig and Teege are descendants of Amon Leopold Goeth, the former commandant of the Płaszów camp. Each grew up without knowing the truth behind their relationship to Goeth and this family secret heavily affected their adult lives.

Holocaust survivors were also affected by the film's release and felt a personal connection to the concentration camp's physical site. Helen Jonas, one of Goeth's maids, returned to the site with his daughter Monika Hertwig. Leon Leyson tried to move on from and block out memory of his past imprisonment at Płaszów until the release of Schindler's List. The film prompted him to reassess his relationship to the past. Bernhard Offen was the opposite of Leyson. He was extremely committed to educating others on what happened at Płaszów and 
wrote a guidebook which was published in 2008 for visitors of the site. These reactions are just three on a diverse scale of how survivors of Płaszów responded to its newfound fame.

\section{Goeth's Daughter: Monika Hertwig}

Monika Hertwig is the child of Amon Goeth and his mistress Ruth Irene Kalder as shown in Figure 1. Her mother worked for Schindler as a secretary, before meeting Goeth and moving into his villa at Płaszów. They had a relationship for several years before he was arrested and executed in 1946. Hertwig was born in Bad Toelz outside of Munich in 1945 and never met her father. Hertwig's mother had raised her to believe that her father had been a soldier killed during the war. When she was eleven years old, she found out the truth-her father was a notorious Nazi. During an argument her mother remarked, "You are like your father, and some day you will die like him." Hertwig wondered what her mother meant by this statement and sought out her grandmother, Agnes Kalder. She was the first person to explain to Hertwig what the Holocaust entailed and that her father had been hanged for his crimes. ${ }^{94}$

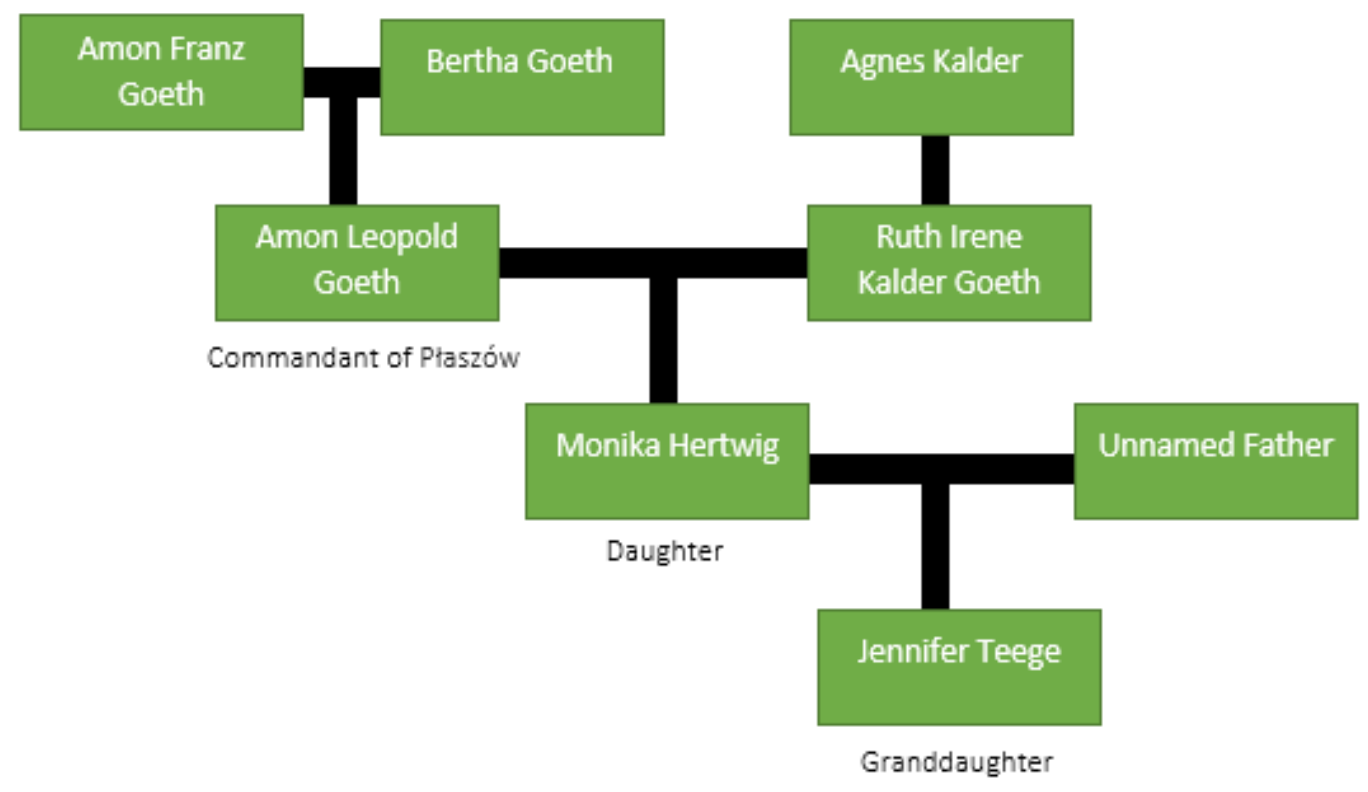

Figure 1: Goeth Family Tree

\footnotetext{
${ }^{94}$ Monika Hertwig and Helen Jonas-Rosenzweig, Inheritance, Documentary, directed by James Moll (Los Angeles, CA: Allentown Productions, 2006).
} 
Years later she read in the newspaper about Spielberg's film. "I went to this film and I was looking for my father," Hertwig said. Noticing Ralph Fiennes’ profile as matching a photograph she had of her father, Hertwig recognized him immediately on the screen. She recounted with tears in her eyes the scene in which a young Jewish woman is killed at the orders of her father. Her reaction to Schindler's List was quite contrary to the praise it had received from the rest of the world. "I started to hate that Spielberg. I hated him," Hertwig exclaimed. She was physically ill after viewing the film, "Spielberg told me the truth and for telling me the truth, I attacked him. Because I didn't know-I didn't want to know everything." 95 It was the first time she recognized the reality of her father's crimes and the extent of his sadistic torture of his prisoners. Out of concern for her physical well-being, her husband had to call a doctor, who explained to Hertwig that her body was responding to shock. ${ }^{96}$

Prompted by questions plaguing her since she discovered the truth, Monika Hertwig visited Płaszów in 2004 and her journey was filmed for a documentary. When researching her father, she learned that he had kept two prisoners in his villa to serve as his maids. Both these women were named Helen, so Goeth referred to Helen Hirsch as "Lena” and Helen Jonas as "Susanna." 97 The documentary's director, James Moll, had previously reached out to Hertwig for the right to use a photograph of her father in a film project. Knowing Moll's involvement in interviewing Schindler's survivors, Hertwig asked if he had contact information for Helen Jonas. After this conversation, Moll met Helen Jonas at a Shoah Foundation event and approached the subject with her. ${ }^{98}$ Hesitant at first, after receiving a letter from Hertwig she agreed to a meeting.

\footnotetext{
95 Ibid.

${ }^{96}$ Hitler's Children, directed by Chanoch Ze'evi (Film Movement, 2011).

${ }^{97}$ Jennifer Teege and Nikola Sellmair, My Grandfather Would Have Shot Me: A Black Woman Discovers Her Family's Nazi Past, translated by Carolin Sommer (New York: Experiment, 2016), 145.

98 “Filmmaker Interview," POV. http://archive.pov.org/inheritance/interview/ (accessed December 29, 2019).
} 
Moll planned for the two women to meet at the location of the former camp in Kraków, Poland. Helen Jonas traveled from the United States and brought her daughter with her. Hertwig traveled from Germany and left her husband and grandson behind.

Helen Sternlicht Jonas, now Helen Jonas-Rosenzweig, had not returned to Poland since the end of the war. Sternlicht was her maiden name and at the time of the film, she was married to her first husband and had taken Jonas as her surname. Hertwig's letter pleading for answers regarding her father and mother gave Jonas the final push to meet with Hertwig. In a hotel room interview, she recounted the story of Goeth selecting her as his personal maid while she was cleaning barracks windows. She was only thirteen years old at the time and it had been her third day living at the camp. She was immediately moved into Goeth's villa where she was afraid of him constantly. Jonas explained, "He lived like a king. [H]e had his mistress with him, and he had those two slaves. And unfortunately, I was one of them."99

The recording of the meeting between Goeth's daughter and Goeth's former prisoner was uncomfortable. Hertwig spent time blaming her mother Ruth and looking for faults in her character, while Jonas was grieving for her murdered family members and reliving harsh memories. Hertwig's childhood was filled with her mother's defense of Goeth's actions. After Hertwig's reciting of some of these anti-Semitic comments, Jonas exclaimed, "Monika, please stop, stop right now."

Their meeting surprised even the documentary's director. Moll had been expecting "some sense of closure, some sense of coming together," but instead their meeting posed more questions for the director. When asked about its theme, Moll remarked that it "raises questions about what our parents did and how we each carry with us the consequences of our parents'

\footnotetext{
${ }^{99}$ Hertwig and Jonas-Rosenzweig, Inheritance.
} 
actions." 100 Hertwig appeared to be living every day by trying to outrun the shadow of her father and his crimes.

Jonas commented, "I need this too," in reference to their trip. Her boyfriend Adam Sztab was caring for her sick mother while she was trapped working in Goeth's villa. When she passed away, Sztab buried her on the grounds. Goeth executed Sztab for his involvement with the resistance within the camp, and Jonas now can never know the location of her mother's final resting place. ${ }^{101}$ For Jonas, the trip provided an opportunity to grieve as well as educate Hertwig about her father.

Goeth's Granddaughter: Jennifer Teege

A German family adopted seven-year-old Jennifer Teege in 1977. Teege had been living with the Sieber family since she was three and before that, in a Catholic orphanage. In 2008, Jennifer Teege picked a book off the Hamburg city library's stacks titled I Have to Love My Father, Don't I? Upon examining the cover further, she noticed its subtitle, The Life Story of Monika Goeth, Daughter of the Concentration Camp Commandant from "Schindler's List." Teege recognized the name Monika Goeth as her birth mother and prior to her adoption, she remembered writing "Jennifer Goeth" on schoolbooks. While struggling to piece together the implications of this finding, she managed to check out the book from the library, thus starting her journey to research her family history.

Teege remembered her birth mother and grandmother and recognized their images in Matthias Kessler's book about Monika Goeth. Ruth and Monika Goeth visited Teege at the orphanage and her foster family from time to time. Upon viewing the images in the book, she

100 "Filmmaker Interview."

${ }^{101}$ Hertwig and Jonas-Rosenzweig. 
realized that the kind grandmother she remembered was Ruth Irene Kalder, Goeth's mistress who shared his villa at Płaszów.

The relationships in this family since the end of the war follow a pattern. Hertwig cherished time with her maternal grandmother Agnes Kalder, but she had a difficult relationship with her mother Ruth Irene Kalder. Her grandmother would answer her questions, while her mother would strike her for asking about her father. She played a supportive role for "the Butcher of Płaszów” even after his death. Kalder formally requested to drop her maiden name and take "Goeth" two years after his execution. Goeth's father supported her request, and since his divorce to his second wife had been finalized years before, it was approved. In 1948, she became Ruth Irene Goeth. ${ }^{102}$

Jennifer Teege was quite fond of her grandmother. She had memories of visiting Ruth's apartment as a young child. While her memories are fuzzy from the passage of time, Teege compared the safety of her apartment to the chaos at her mother's home. Monika Hertwig's first husband, an abusive alcoholic, did not exist inside Ruth Goeth's “clean and tidy” space. ${ }^{103}$ Teege's image of her grandmother was that of a young, independent and progressive woman. She worked as a secretary for Goethe Institute after the war in order to take care of herself and daughter. For a period, she lived with a cross-dresser and later an African man, a friend of Teege's father. Teege saw her as an open-minded individual, "she was no racist."104

When she discovered the truth of her heritage, Teege's image of her grandmother was shattered, and her perspective of her mother changed. Jennifer "no longer [saw] her simply as a mother who abandoned her child; now [she] see[s] her as the daughter of Amon Goeth - the

\footnotetext{
102 Teege and Sellmair, 78.

${ }^{103}$ Ibid., 68-69.

${ }^{104}$ Ibid., 80.
} 
father who became the story of her life, the story that shaped her [Hertwig's] identity." Jennifer concluded that her mother's search for her identity "occupied her to such an extent that it left no room for other people, for her role as a mother, or for me."105

Jennifer Teege did not seek out Spielberg's film like Hertwig had, and at the time of its release, she certainly was not aware she was the granddaughter of the famous camp commandant. She had first watched the film while a student in Israel, but at the time she had not realized her relation to the character portrayed by Ralph Fiennes. Teege admitted she did not watch the film upon its release, but finally watched it on TV while alone in her Tel Aviv apartment. In her opinion, Spielberg's production was "too kitschy, too Hollywood."106 Just as Hertwig had anticipated watching Schindler's List to see her father, Jennifer watched Moll's documentary Inheritance to learn of her mother. The day after Jennifer had stumbled upon her mother's book was the first time the documentary played on German television. 107 "What does she look like, how does she move, how does she talk? Am I like her?" were questions running through her head. ${ }^{108}$ Hertwig had left four-week-old Teege in the care of the Salberg House, a Catholic orphanage, but would occasionally visit. ${ }^{109}$ At the time, she was working as a secretary, battling mental illness, and living with an abusive husband. ${ }^{110}$ When Jennifer turned six, Hertwig was pregnant with her half-sister and consented to her older daughter's adoption by her foster family. Up until this point, Jennifer had had occasional visits with either Hertwig or her grandmother Ruth, but they were inconsistent and ended after the finalization of her adoption. ${ }^{111}$

\footnotetext{
105 Ibid., 99.

106 Ibid., 3.

${ }^{107}$ Ibid., 137.

108 Ibid., 10.

${ }^{109}$ Ibid., 109, 100.

${ }^{110}$ Ibid., 103, 110.

${ }^{111}$ Ibid., 121.
} 
Teege's search for her identity mirrors her mother's actions. Once they each learned the truth, life as they knew it ended. They went down paths of self-discovery, questioning their commonalities with Amon Goeth and struggling to fit into society. This journey began with researching Goeth and his crimes, included a pilgrimage to Płaszów, and lastly required reflection and continuing education in the public sphere. For Monika Hertwig, her initial reflection is in Matthias Kessler's book that Teege discovered in 2008. The book was published in 2002 after a "long, torturous" interview with filmmaker Kessler, in which Hertwig felt conflicted about her emotions for her parents. ${ }^{112}$ Her next public form of reflection occurred in James Moll's documentary in which Hertwig returned to the site with a former inmate of her father. In 2013, Jennifer Teege published her own reflective memoir titled My Grandfather Would Have Shot Me. The title comes from Teege's belief that Amon Goeth's commitment to the Nazi regime's racial policies would have prevented him from having a typical relationship to his bi-racial granddaughter.

Monika Hertwig and Jennifer Teege both struggled with their identity and what it meant to be related to an infamous Nazi. While their stories of discovering their familial connection were different, their next steps were quite similar. Both women, struggling with their identity, researched more about the Holocaust and visited Kraków to tour the site of the former Płaszów camp. It was not enough to read about the events that occurred in Poland, but they each felt compelled to travel to the physical site in order to understand the history.

Jennifer Teege’s trip to Płaszów was more private than that of her mother. One year after discovering her mother's book and watching the documentary, she decided to travel to Poland. She remarked, "I want to see where my grandfather committed his murders. I want to get close to

112 Ibid., 137. 
him — and then put some distance between him and me."113 Upon reflection years later, she admitted, "I went to Kraków to get closer to the overwhelming figure of Amon Goeth, to understand why he destroyed my family."114

She toured her grandfather's villa and recognized several rooms from her mother's documentary. Her Polish tour guide had contacted the elderly man living in the home and he was pleased to show them around the structure. Just as Hertwig had questioned Helen on what her mother did or could have done, Teege posed similar questions of how her grandmother, whom she remembered fondly, had lived in the vicinity of such violence. ${ }^{115}$ Teege did not disclose her relation to Goeth until her tour guide commented about meeting Goeth's daughter one day at the site. ${ }^{116}$ Teege continued to feel guilt and shame over her family's past.

Teege also participated in a Schindler's List tour, which included Kazimierz, the former Jewish quarter, the old Jewish cemetery and a synagogue. ${ }^{117}$ She visited Oskar Schindler's former enamelware factory, which had been converted into a museum by the time of her visit. In the last room is a model of the Płaszów camp, where she examined the proximity of Goeth's villa to the camp. ${ }^{118}$ Her grandmother had remained insistent in later interviews that Płaszów was only a labor camp, not a concentration camp, and that the prisoners were only adults, with no young children. ${ }^{119}$ Both assertions were false. She would also say that she had never been in the camp, but Hertwig would examine the closeness of the villa to the camp to disprove her lies.

Teege could not confront her grandfather directly, but she could visit the physical location where he had lived for years, torturing the prisoners of Płaszów. Her book provides

\footnotetext{
113 Ibid., 27.

114 Ibid., 199.

115 Ibid., 32.

116 Ibid., 42 .

117 Ibid., 43

118 Ibid., 46.

119 Ibid., 71.
} 
readers a glimpse into her inner thoughts: "The moment I laid flowers at Płaszów memorial, I felt as if a huge weight had been lifted from my shoulders." ${ }^{120}$ In a sense, the trip had brought closure to her identity quest. She would struggle to share her story publicly, especially with her Israeli friends, but this initial trip provided some relief to her pain.

Hertwig claimed that she had no knowledge of the Holocaust prior to the conversation with her grandmother Agnes Kalder. She did not know of "any Jews other than Jesus", and certainly did not associate them with people living in Poland or Germany. ${ }^{121}$ Teege, by contrast, had grown up in Munich learning about the Nazi regime's crimes. On one occasion, her class took a field trip to the Dachau concentration camp and she often read books on the subject, including Anne Frank's diary. ${ }^{122}$ She did not see it as a part of her own story, however.

While walking through Goeth's villa, Teege pondered her relationship to her grandfather. "Do I see him as a grandfather or as a historical character? He is both to me: Płaszów camp commandant Amon Goeth, and my grandfather." 123 Teege felt a personal connection and devotion to a physical site because of the actions of her grandfather. Because of her family roots, the landscape became important to her. Similarly, Spielberg's film, which she had overlooked and shrugged off in the mid-1990s now held an importance to her, with its depiction of her grandfather, who became a notorious figure. Even if viewers do not remember the name of the infamous camp commandant, they remember the scenes of the terror of the camp's prisoners in reach of his sporadic, violent behavior. The scenes of Goeth terrifying his maid Helena and shooting Jews from his villa balcony commonly come to mind. Much like Schindler's List

\footnotetext{
${ }^{120}$ Ibid., 98.

${ }^{121}$ Hertwig and Jonas-Rosenzweig.

122 Teege and Sellmair, 24.

123 Ibid., 24.
} 
brought Płaszów to the world, it also spread Amon Goeth's reputation as the "Butcher of Płaszów."

After each had made identity pilgrimages to Płaszów, Hertwig and Teege both moved on to teach younger generations about the Holocaust. Teege returned to the site in 2012 at the request of her Israeli friend Anat to speak with her son's class. ${ }^{124}$ This marked her first public speaking engagement to tell the story of her family history and it occurred only three years after her first visit to Płaszów. Now Teege tours schools, often speaking to students about her journey. Hertwig has also returned to the site with students, and once led a tour accompanied by another Nazi's son. ${ }^{125}$ The PBS documentary Inheritance has an accompanying discussion guide that includes profiles of each person involved, background information about the site and Goeth, and resources for people to continue Holocaust research. ${ }^{126}$

Descendants of Nazis pushing for more Holocaust education is not uncommon, especially among those of prominent Nazis. In Hitler's Children, Monika Hertwig was included among other descendants of Nazis who share similar issues in discovering their identity and suffering from guilt. Other individuals interviewed include descendants of Hermann Goering, Heinrich Himmler, and Hans Frank to show how this legacy has affected their lives. Some avoid the topic and confrontation altogether. They have given up speaking German, kept an ex-spouse's last name, or moved to another country to live in anonymity. Others have taken a more direct role. The great niece of Goering explained that she and her brother made the decision to be the last of the Goering line and each had sterilization procedures. Niklas Frank has chosen the same path as Hertwig and Teege to educate the public. The son of Hans Frank, the Governor-General of the

\footnotetext{
${ }^{124}$ Ibid., 197-199.

125 Ibid., 42.

${ }^{126}$ Faith Rogow, "P.O.V. Discussion Guide: Inheritance.” American Documentary Inc., 2008.
} 
Nazi occupation zone in Poland, Nicklas Frank has written books, visited classrooms, and been interviewed for documentaries so an international audience can learn of the crimes of his parents. $^{127}$

Descendants of Amon Goeth are not the only individuals returning to the site of their family's crimes. The reaction of the grandson of Auschwitz commandant Rudolf Hoess to the site was recorded in the Hitler's Children documentary. He obsessed over the family photographs he had of his father and grandfather from the family home near the camp. Walking through the space, he held historical photos up to match their modern-day location. Hoess specifically was intrigued by the gate and wondered how his family lived in such a luxurious style while people were suffering. When asked by a touring student about the reason for his visit, Hoess replied, "To see the horrors of what my grandfather made and the lies [of his family] for years." Like Hertwig and Teege, Hoess was plagued with guilt and questioned his identity, but he continued to share his story and the fight against hatred.

Survivors sometimes make the journey to return to the place of their former imprisonment. Tim Cole identified potential motives for this return visitation by examining the relationship between returning Auschwitz survivors and the physical location or remains at the site. Cole concluded there were three types of sites a survivor was motivated to visit. The first location was the gas chambers and crematoria, where survivors could mourn their loss in a collective, shared space. The second type of site was personal spaces, such as their formerly assigned barracks, where the survivors became educators and told their stories. Lastly, some survivors returned and visited the Nazi-controlled spaces. This could be a gate or a guard tower to which they were denied access as Jewish prisoners. Entering these spaces, survivors felt a

${ }^{127}$ Hitler's Children, directed by Chanoch Ze'evi (Film Movement, 2011). 
sense of liberation and revenge against the Nazi regime by outlasting it. ${ }^{128}$ In the experience of Helena Jonas, walking Monika Hertwig through the campgrounds and Goeth's villa allowed her to mourn for her lost family members and tell her personal stories. Jonas' experience did not align with the last category, perhaps because she was struggling with Hertwig's presence still at the site.

Goeth's Victims: Survivors Helen Sternlicht Jonas-Rosenzweig, Leon Leyson, \& Bernhard $\underline{\text { Offen }}$

Survivors of Płaszów reacted to the film Schindler's List and the Płaszów site in different ways. Some concentration camp survivors felt obligated to bring their children and their grandchildren to their place of imprisonment to educate the next generation. ${ }^{129}$ For this reason, they seemed to find a commonality with certain Nazi descendants. Monika Hertwig was not the only descendent to return to a former camp location with its survivor. Helen Jonas brought her daughter to accompany her on the journey and learn about her personal stories. Returning to the physical site was important to Jonas and showing Hertwig the landscape was necessary in confronting her with the reality of the situation. Like Hoess's obsession with his grandfather's gate at his home near Auschwitz, Hertwig became interested in the closeness of the villa to the camp. She wanted to confront the idea that her mother was unaware of Goeth's crimes and in order to do so, she had to take a pilgrimage to Płaszów.

After liberation, Jonas-Rosenzweig wanted to leave the city of Kraków immediately. She commented, "I had a bad experience. I was walking in the streets of Kraków and I felt like the ground was falling under me. I guess I felt like this was not a safe place for me, like they don't

\footnotetext{
${ }^{128}$ Tim Cole, "Crematoria, Barracks, Gateways: Survivors' Return Visits to the Memory Landscapes of Auschwitz." History and Memory: Studies in Representation of the Past, 25, 2 (2013), 104.

${ }^{129}$ Ibid., 111.
} 
want me there. That stayed with me for life. I wanted to get out of there as quick as I could."130 Helen was contacted when Keneally was researching for his Schindler's List book, but it came only a few months after her husband's sudden death and she was consumed with mourning. ${ }^{131}$ While her story was not included, Amon Goeth had two maids originally named Helena whom he kept in his villa. The maid portrayed in the film was Helen Hirsh, the other maid who worked alongside Jonas-Rosenzweig. Jonas-Rosenzweig finally returned to the Płaszów site in 2004, after she was contacted by Amon Goeth's daughter. ${ }^{132}$ It is unknown if Jonas-Rosenzweig returned again after this documentary, but the trip was visibly traumatic for her. While she may have only returned once to the site, her personal account is forever recorded in Moll's documentary.

Survivor Leon Leyson was reluctant to speak about his experience after the war. He was about thirteen years old when he was moved from the ghetto to the camp, and he became one of the youngest of the "Schindlerjuden." Spielberg's film changed his life. "Until the film I had remained mostly silent about my past. When there was such enormous interest in the movie, I began rethinking my reluctance to talk about my experiences," Leyson reflected. After the movie came out, Leyson was contacted by Los Angeles Times reporter Dennis McLellan and after a little pushing from McLellan, he agreed to a first interview. ${ }^{133}$ This prompted Leyson to begin sharing more of his experience in the concentration camps and life under the Nazi regime. He slowly became more comfortable with accepting speaking invitations. After meeting the director of the Holocaust education center at Chapman University in California in 1995, Leyson became

\footnotetext{
${ }^{130}$ Elinor J. Brecher, Schindler's Legacy: True Stories of the List Survivors (New York: Dutton, 1994$), 72$.

${ }^{131}$ Ibid., 74.

132 Hertwig and Jonas-Rosenzweig.

${ }^{133}$ Leon Leyson, The Boy on the Wooden Box: How the Impossible Became Possible... On Schindler's List (New York: Atheneum Books for Young Readers, 2013), 198.
} 
a regular speaker. In 2008, his story was told in a half-hour news special titled, A Child on Schindler's List. ${ }^{134}$

His memoir was published in 2013, the year after he passed away. The title, The Boy on the Wooden Box, referred to how he relied on a box to help him reach the machine controls. ${ }^{135}$ His memoir focused on his time in the Kraków ghetto and Płaszów camp. Leyson wrote, "My first impression of Płaszów as hell on earth never changed. I only needed one look to see that this was an entirely foreign place... Płaszów was an alien world... It was barren, dismal, chaotic. Rocks, direct, barbed wire, ferocious dogs, menacing dogs, and acre after acre of drab barracks stretched as far as I could see...The moment I entered the gates of Płaszów, I was convinced I would never leave alive." ${ }^{\prime 36}$ He was moved to the Emalia sub-camp around the spring of 1944 and transferred to Gross-Rosen on October $15 .{ }^{137}$

It is unclear whether Leyson returned to the site of the former concentration camp after liberation. However, he did return to Poland in 1989. His family toured his hometown of Narewka in eastern Poland near the border with Belarus and even though their guide was unfamiliar with the massacre of the Jewish population of Narewka, they found the monument to its victims that had become overgrown with weeds. ${ }^{138}$

While Leyson may not have returned to Płaszów, Bernard Offen often did. Offen was born in Kraków and moved to the United States after the war. He spent his winters in California and his summers in Kraków giving public tours of the ghetto area and Płaszów site. Offen acted as the "lone guardian of memory in an amnesiac landscape," giving daily tours and promoting

\footnotetext{
${ }^{134}$ Ibid., 200-201.

135 Ibid., 3.

${ }^{136}$ Ibid., 113-114.

137 Ibid., 133, 150-152.

${ }^{138}$ Brecher, 98.
} 
his handmade films. Offen's first trip back to Poland was in 1981 and he began making regular trips to Kraków in $1991 .{ }^{139}$ Fearing for the future of the site, Offen founded the "Bernard Offen Dialogue Club of Kraków" in 2004, which trained locals on the site's historical value and who served as guides in Offen's absence. He also took an active role in pushing city officials for more signage at the site of the former camp. ${ }^{140} \mathrm{~A}$ few years later Offen wrote a guidebook titled $M y$ Hometown Concentration Camp: A Survivor's Account of Life in the Kraków Ghetto and Płaszów Concentration Camp. It gave a personal narrative as well as visitors information of what they could expect at the modern site. ${ }^{141}$

Whether they returned to the site on a personal pilgrimage, wrote a memoir or a guidebook, or gave public tours of the site, Płaszów remained important for each of these three survivors. Like Goeth's descendants, they felt compelled to visit or preserve the memory of the site. The physical location drew them back and had a powerful impact on their lives. Płaszów remained relevant in the lives of those impacted by its history, and their interaction with it served to further the preservation of its memory.

\footnotetext{
${ }^{139}$ Offen and Jacobs, xviii.

${ }^{140}$ Lehrer, 45.

${ }^{141}$ Offen and Jacobs.
} 


\section{Chapter 3}

\section{The Film's Lasting Impact on the Site Today}

The decision to film Schindler's List near the original site of Płaszów impacted the site beyond increasing tourism to the area. The film's success placed international attention on a site which had previously been ignored by Kraków's residents, and it saved the site from potential commercial developments.

The city had been developing plans for what to do with the empty space for years before the successful film. In the 1970s and 1980s, these plans included the creation of Contemplation Park, a recreation area for nearby city residents. Part of the potential development included the addition of "walking paths, trees, bushes, flowerbeds, viewing platforms, stairs, and optionally areas of water." Other plans included a potential restaurant and possibly turning the Liban quarry near the park into "open-air swimming pools." 142 According to Katarzyna Kocik of the Historical Museum of the City of Kraków, local support for the site's development was positive, but it may have failed due to the political changes resulting from "the collapse of communism, the growth of historical awareness, and the reorganization of the structures of local authorities." This increase of historical awareness can be credited to Spielberg. With his reputation as a director and the vast attention the project received, it was reasonable to suspect that the sites involved in the film, both the film set and the historical sites portrayed, would be affected by his film project. Public attention on the Liban Quarry and Płaszów’s green landscape would increase.

\footnotetext{
142 Śmietana and Bednarek, 128.
} 
In the years after filming had ceased, the city of Kraków would continue to discuss options for enhancing education about the site. Among other proposed options was the use of Schindler's List set in the quarry as an educational tool. However, the city struggled to receive support for any of these options. ${ }^{143}$ The larger priority was to place the site on the register of monuments for preservation and access to resources. The Council of the Memory of Struggle and Martyrdom required local authorities to place the site on the register of monuments and have documentation of ownership before it could assist "both in consultations and in finances." The council’s Secretary General, Andrzej Przewoźnik, blamed Kraków’s leaders for lack of action regarding Płaszów and claimed "the only action undertaken by the authorities of Kraków is the laying of the flowers under the monument once a year... Everything points to the fact that no one in Kraków is interested. Care for the place is an issue of decency, responsibility, and respect for ourselves." Katarzyna Kocik's report also listed the lack of documentation of the site as an issue, stating "The lack of any information concerning the role of the area during the war and treating it as a place of recreation were serious problems."144

Her account of improperly using the site as a place of recreation is not unique. Survivors and other visitors have written about their experiences at the site, witnessing its usage as a green area. Gary Schiff described the site after his 2009 summer trip. Schiff claimed, "despite that worldwide notoriety, the camp is in a state of abject neglect, so completely overgrown with weeds as to render it virtually invisible in the surrounding urban landscape to all but those who are determined to find it." As he asked around, "no one in the area could even tell [him] where the site was," until finally an elderly Polish man volunteered to take him. He commented that

\footnotetext{
${ }^{143}$ Ibid., 131.

${ }^{144}$ Ibid., 132.
} 
Goeth's villa remained standing as an "unmarked and unkempt...modest residence, complete with the ubiquitous satellite dish."145

Spielberg's film had a lasting impact on Kraków’s tourism and brought Płaszów’s site to the attention of many who otherwise would have ignored it. By examining visitor experiences at the site, the city's increased involvement, and on-going issues with the site, this chapter will provide a comprehensive image of what Płaszów looks like today.

This past year, over 14 million people traveled to Kraków. Of this number, 30.5\% reported their reason for travel was for its monuments. The city is known for its historic district and cultural landmarks. ${ }^{146}$ Visitor numbers to Płaszów are not officially recorded because it is presented as an open-air commemorative park. The former concentration camp also does not have its own museum or interpretative staff. In order to examine its visitor interactions, one has to consult web sources. Some visitors have posted their experiences online through websites like TripAdvisor, while others have decided to construct their own website in order to educate others about the site. YouTube video tours are also popular, and they assist in explaining the complicated landscape to visitors.

According to TripAdvisor, the city's top attraction is the Rynek Glowny Central Square. Several other historic cultural landmarks are listed including St. Mary's Basilica and the Wawel Royal Castle. What one may not expect is that the former Jewish district of Kazimierz is listed as the second most popular landmark. The Schindler's Factory museum is listed as number twelve

\footnotetext{
${ }^{145}$ Gary S. Schiff, In Search of Polin: Chasing Jewish Ghosts in Today's Poland, Washington College Studies in Religion, Politics, and Culture, 2. (New York: Peter Lang, 2012), 59.

${ }^{146}$ Krakow Convention Bureau, "More Than 14 Million Tourists Have Visited Krakow," Magiczny Kraków. https://www.krakow.pl/ccb_en/more_news__/235830,1441,komunikat,more_than_14_million_tourists_have_visit ed_krakow.html (retrieved January 10, 2020).
} 
and the Ghetto Heroes Square memorial is listed at fourteen. ${ }^{147}$ These numbers show that Kraków's tourism is highly related to sites associated with World War II and furthermore those featured in Spielberg’s film. Much further down the list at forty-six is Płaszów. ${ }^{148}$

Reading the comments on TripAdvisor's Płaszów page provides an insight into visitor perspectives over the years. Eleven years ago, user "bookratt" wrote on the situation regarding the confusing landscape. He commented, "The part of the camp that we viewed was overgrown, partially unfenced and looked neglected. The natural cave on the property is full of homeless men/drunks who light fires and throw their vodka and beer bottles everywhere at night." The lack of signage and interpretation were also identified as major issues.

Signage at the site was a large problem. Without signs marking the area, the large green space appeared as just another city park. Additionally, the lack of any interpretation pieces allowed the public to ignore the historical context of the site. This changed in March 2003 when signs were installed to mark the former concentration camp's boundaries. They were installed by the Centre for Cultural and Environmental Education and read, "Ladies and Gentlemen! You are entering the area of the former concentration camp Płaszów. Please act according to the solemnity of the place." ${ }^{149}$ While these markers were a positive addition, they did not provide any additional historical context. This would be one task the city's museum would accomplish in more recent years.

147 “Top Attractions in Krakow," TripAdvisor, accessed November 18, 2019; https://www.tripadvisor.com/Attractions-g274772-ActivitiesKrakow_Lesser_Poland_Province_Southern_Poland.html\#FILTERED_LIST 148 "Plaszow Concentration Camp," TripAdvisor, accessed November 18, 2019; https://www.tripadvisor.com/Attraction_Review-g274772-d1206588-Reviews-Plaszow_Concentration_CampKrakow_Lesser_Poland_Province_Southern_Poland.html

${ }^{149}$ Śmietana and Bednarek, 134. 
Since the city museum became involved with Płaszów in 2016, progress has been on increasing public awareness of the site's historical context. A conference, Discovering Płaszów, was held on April 15 and 16 the same year to bring more attention on the site. The publication that followed shared the conference's title and is the most comprehensive source documenting the landscape of the site. Its ten chapters focus on the current status of the site's landscape and the previous attempts at commemoration. ${ }^{150}$ They also published a report, KL Plaszow: Report for the Period 2016-17, which documented the museum's involvement with the site. According to this report, the museum received financial support through a Ministry of Culture and National Heritage grant, co-funded by the city, to continue research and public education on Płaszów. ${ }^{151}$ The report explained there is a "great demand" for more historical context at the site and used the 200 visitors who attended the museum's first open tour of the camp in April 2015 as an example. ${ }^{152}$ The KL Plaszow: Report for the Period 2016-17 also targeted the current use of the site as problematic. In discussing the Discovering Plaszow conference, it read, "The contrast between today's use of the post-camp area (walking dogs, jogging, sunbathing, et cetera) with the historical truth about the past was intended to educate the viewers and make them aware of the gravity of the problem." 153

The museum began a digital archive for Płaszów in 2018. It was part of a two-year project funded by the Ministry of Culture and National Heritage and the Municipality of Kraków. The website describes its goal as "gather[ing] and provid[ing] knowledge about the former Nazi German labour and concentration camp of Plaszow, but above all, it is a token of

\footnotetext{
${ }^{150}$ Śmietana and Bednarek, 134.

${ }^{151}$ Monika Bednarek, Kamil Karski, and Marta Śmietana, ed. KL Plaszow: Report for the Period 2016-17. (Krakow: Historical Museum of the City of Kraków, 2018), 9.

152 Ibid., 14.

${ }^{153}$ Ibid., 60.
} 
remembrance for prisoners and victims of the camp." The archive is divided into six sections including prisoners, camp crew, photographs, audio-video, bibliography, and artifacts. The archive currently has only 5356 objects, but the page encourages its visitors to email them if they would like to add the collection. ${ }^{154}$

On January 26, 2017, the city of Kraków, the Jewish community of Kraków, and the Historical Museum of the City of Kraków signed an agreement to reestablish the site as a memorial space. The preamble read, "The duty to preserve the memory of suffering and death of KL Plaszow prisoners is a foundation on which we will build a common civil society. We, representatives of three institutions for which the memory of the past serving as building material for the future is particularly important, undertake a joint effort aimed at creating a coherent commemoration, adequately reflecting the enormity of crimes perpetrated in the former KL Plaszow camp. Memory is a deposit from which we, contemporary citizens, not only should, but also have the duty to prudently draw upon, so that the future does not repeat the mistakes of history." $" 155$

The plans to "restore the memory" at the Płaszów site had two parts. First, the emptiness of former camp's landscape needed to be addressed. They installed "historical checkpoints and field posts" to increase interpretation at the site. According to the 2016-17 report, "The historical checkpoints will define the main sight-seeing route. They will have the form of simple boards with a historical photograph and a brief commentary in three languages (Polish, English, and Hebrew). The field posts will be small signs by camp remnants, also those discovered during archaeological excavations and in places located outside the main sight-seeing route, but

\footnotetext{
${ }^{154}$ Museum of Krakow, "Digital Archive of KL Plaszow,” https://ca.muzeumkrakowa.pl/

${ }^{155}$ Bednarek, Karski, and Śmietana, 3.
} 
important for the history of the camp." The second part of the recent plan included the creation of a permanent exhibition. It will be housed in two buildings, the Grey House and the Memorial, and focus on presenting the artifacts found during excavations at the site. ${ }^{156}$

By late 2017, interpretation panels were placed around the site with large images of historical photos and text. ${ }^{157}$ The addition of this open-air exhibit clarified the landscape's history for visitors. In September 2019, Conner B. commented, “There are signs across the camp letting you know the main areas. There is a memorial dedicated to the former prisoners. The camp itself is more of a park nowadays, places to walk as well as think and reflect. It was incredibly peaceful allowing us to reflect on the camp and what took place there."158

The lack of signage was not the only issue that led to confusion at Płaszów. Sources about the site continue to confuse the film and the historical settings. According to In Your Pocket: Essential City Guides, the Grey House building served as Goeth's villa in the film. ${ }^{159}$ A YouTube video also falsely labels the Grey House as the film's villa. ${ }^{160}$ Challenging this is Allan Starski, the production designer, who described the villa as one of the pieces reconstructed near the quarry. ${ }^{161}$

While the signage added at Płaszów increased visitor understanding of its historical context, there have been additional issues at the site. Because of the easy accessibility of the site, it also has become a target of vandals.

\footnotetext{
156 Ibid., 47-48.

${ }^{157}$ Kamil Karski (The Historical Museum of the City of Krakow), email to author, February 11, 2020.

158 "Plaszow Concentration Camp."

159 "Grey House," In Your Pocket: Essential City Guides, March 20, 2019, accessed April 01, 2019; https://www.inyourpocket.com/krakow/grey-house 112729v.

${ }^{160}$ dzikieswinie - Motorcycle Club and Adventures. "Amon Goeth's villa in Schindler's List (not the real house)." YouTube video, 1:01. December 7, 2014. https://www.youtube.com/watch?v=k5L2kH3z6Eo

${ }^{161}$ Shoah Foundation, 45.
} 
In March 2010, the large monument, the Memorial to the Victims of Fascism in Kraków, was vandalized. Swastikas, the Star of David, and large red letters reading "Jude Raus," German for "Jew Out" and "Hitler Good" were on the back of the monument. One of the smaller memorial plaques was also covered with a swastika and "Jude Raus." 162 Monuments were not the only things targeted by anti-Semitic vandals. According to one visitor's TripAdvisor review, Goeth's villa was often a target of anti-Semitic vandalism. This visitor also believed the villa was "viewed as a shrine to him [Goeth] by the neo-Nazi movement all across Europe and the world." At the time of his post, in April 2008, there were anti-semitic slurs spray painted across the villa’s garden gate. ${ }^{163}$

Vandalism is not the only thing that landed Goeth's villa in the public's attention. While the property had fallen into a state of disrepair after the war, it recently was renovated. This was not without controversy, as some felt it should remain in its crumbling state. In the documentary capturing Monika Hertwig and Helen Jonas meeting at the site, they each commented about the age of the building. The crumbling exterior allowed them to see that a part of Goeth was crumbling into the past.

Artur Niemyski, a developer, purchased the property in 2015 with the intent to renovate it as a family home. Niemyski said, "This building was occupied for a small period of time by the Nazi, which should not influence this property forever... Many houses in the area were occupied by Nazis... I want to restore the house to be once again a Polish family house and keep it like

\footnotetext{
162 The Associated Press, "Plaszow Camp Holocaust Monument in Poland Vandalized.” March 13, 2010; https://isurvived.org/InTheNews/PlaszowCamp-vandalism.html

163 "Plaszow Concentration Camp."
} 
this." Additionally, he announced there will no longer be any educational tours of the home, but visitors would still have a right to take photographs of the exterior from the street. ${ }^{164}$

Some claimed that the "renovation of the home was whitewashing its sinister past."

Rabbi Naftali Schiff explained, "We welcome dialogue with the owner, but he has made it clear to us that he wants the world to forget what happened there." Schiff is the founder of the British charity, JRoots, the organization had brought groups to the "dilapidated" villa in past years. They also started a campaign to have the villa preserved as a memorial site. Goeth's former maid Helen Jonas-Rosenzweig advocated for JRoot's plan to make the villa a memorial. She commented, "I was a prisoner in this house and a victim. I want the world to learn what happened there."165 The organization started an online petition on Change.org which attracted about 300 signatures within twenty-four hours. The goal was to bring awareness to the issue of converting the historical site into a "luxury villa" and ask the city government to step in.

According to a few articles, the previous owner had made attempts to sell the property to the city in order to convert it to a museum, but the attempts were unsuccessful. ${ }^{166}$ Unfortunately for the Jroots organization, Niemyski purchased the building and completed the renovation of his private home. Niemyski plans to convert the basement into a workshop or a wine cellar. ${ }^{167}$

Steven Spielberg's Schindler's List drew international attention on Płaszów. Visitors were confused at the site due to the lack of signage and leftover ruins from the film set. Often,

\footnotetext{
164 Stuart Winer, "Notorious Nazi’s house of horrors to become a luxury villa." The Times of Israel. February 9 , 2017. https://www.timesofisrael.com/notorious-nazis-house-of-horrors-to-become-a-luxury-villa/

165 Ibid.

166 Beckie Strum, “Backlash Over Nazi’s Polish Home Becoming a Luxury Villa.” Mansion Global. February 9, 2017. https://www.mansionglobal.com/articles/backlash-over-nazi-s-polish-home-becoming-a-luxury-villa-53671 167 Jake Wallis Simons, "Who would live in a house like this? Schindler's List 'House of Horrors' where Nazi butcher Amon Göth shot Jews from the balcony and his dogs ripped victims apart is being turned into a LUXURY VILLA.” DailyMail. February 8, 2017. https://www.dailymail.co.uk/news/article-4197060/Schindler-s-List-HouseHorrors.html
} 
they were taken back by the residents using it as green space to sunbathe and engage in recreational activities. By 2016, the Historical Museum of Kraków joined the city in its effort to reclaim the site as a memorial and increase awareness of its historical context.

The project which placed nineteen signs of historical context around the site is a temporary solution while the museum finalizes the plans to install the permanent exhibit. The addition of these signs to the landscape can be viewed a success in itself as it marked a step in the right direction to increase visitors' understanding of the site's historical context. Jason Francisco, a writer and photographer, is a frequent visitor to Płaszów and has documented the site for eight years. Francisco wrote, "Just seeing them from a distance, I felt a palpable sense of victory - that after 70 years of neglect and avoidance, at least now there is rudimentary in-situ historical information placed there." ${ }^{168}$ However, this sense of accomplishment faded when he took a closer look at the signs. In an online text-and-photo essay, "Clear and Not Clear Enough," Francisco criticized the new signs for being just that, "clear and not clear enough."

According to Francisco, "the heart of the challenge at Płaszów is changing the perception of the site among locals, whose behavior attests to an incomprehension of the site's genocidal history — and functionally a denial of it." His photographs captured people doing various outdoor activities including sunbathing, drinking, and walking their dogs through the former concentration camp. The lack of a concise memorialization plan has resulted in Płaszów becoming "a space that is both a known territory of genocide and a de-facto public park, popular among dog-walkers and hikers, and in the warm months among sunbathers, picknickers and drinkers."169 This described behavior matched with the author's experience during her 2014 trip

\footnotetext{
168 Jason Francisco, "Clear and Not Clear Enough," http://jasonfrancisco.net/clear-and-not-clear-enough (accessed on March 10, 2020).

${ }^{169}$ Ibid.
} 
to the site. As Figure 2 shows, a child flew a kite beside the Monument Against Fascism and bicycles and other outdoor sports equipment rested in an area where the camp's prisoners were killed. Figures 3 and 4 show locals sunbathing and drinking, as well as modern development encroaching on the site.

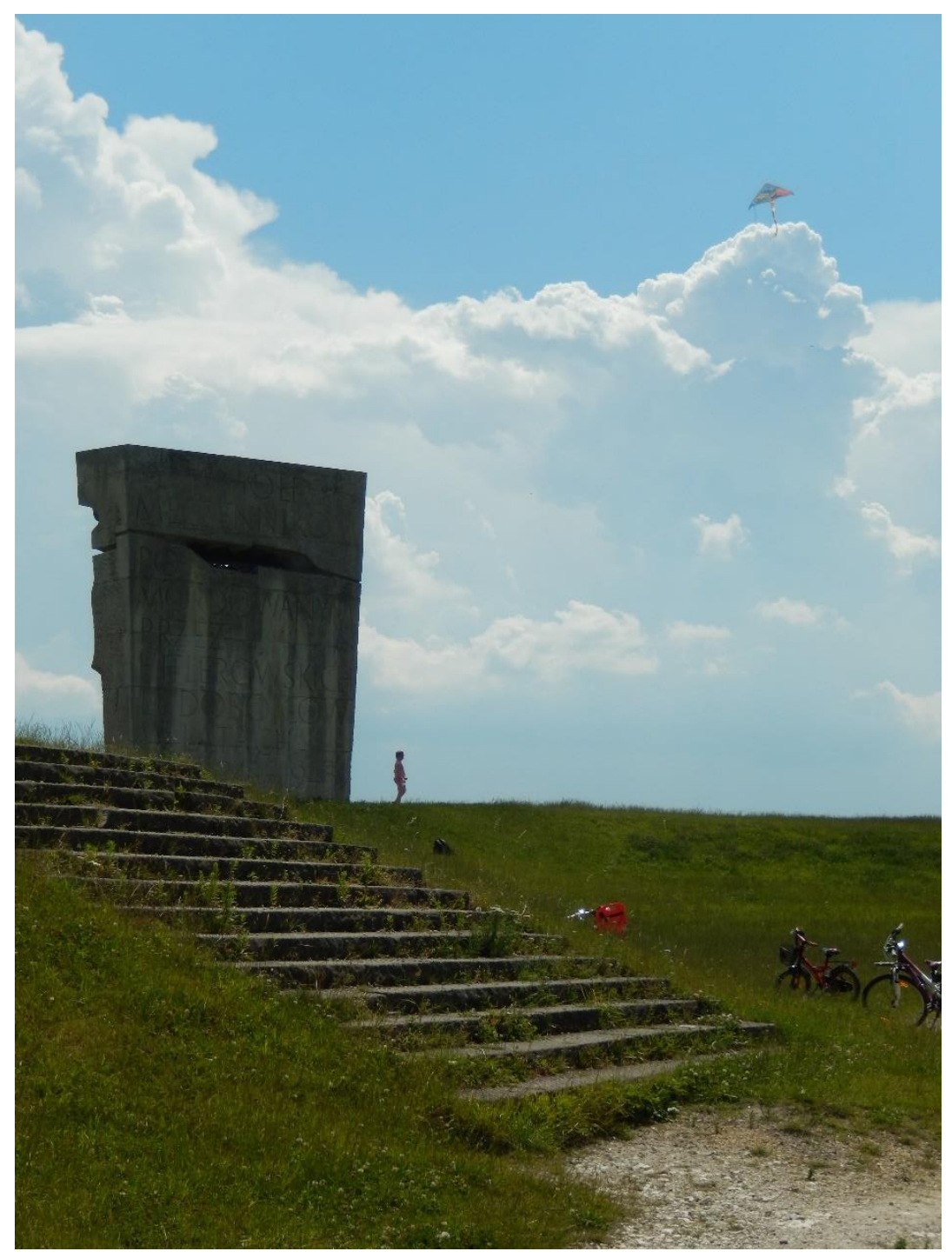

Figure 2: Child flies kite beside Monument Against Fascism. Photo from author, 2014. 


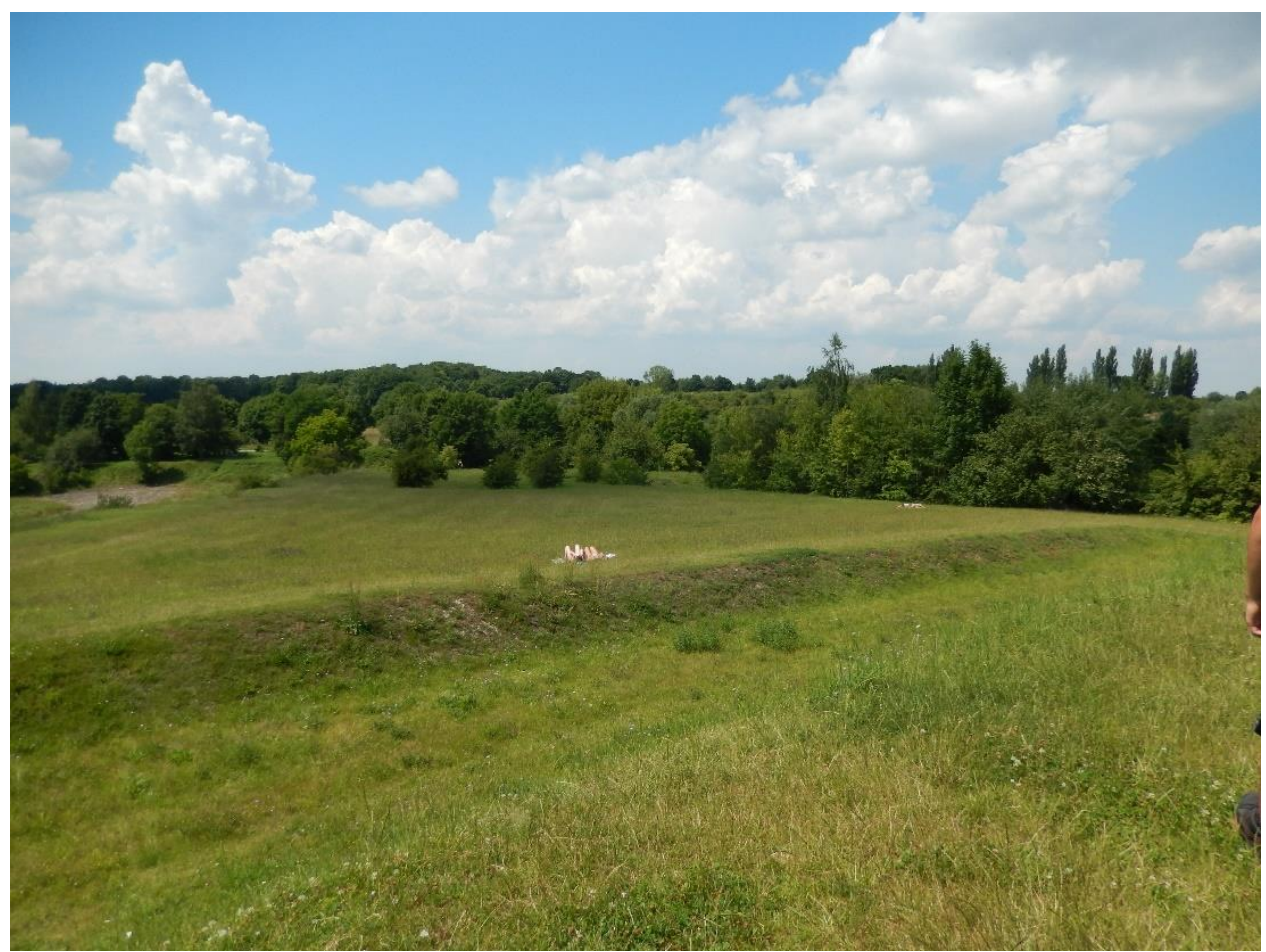

Figure 3: Sunbathers at the site. Photo from author, 2014.

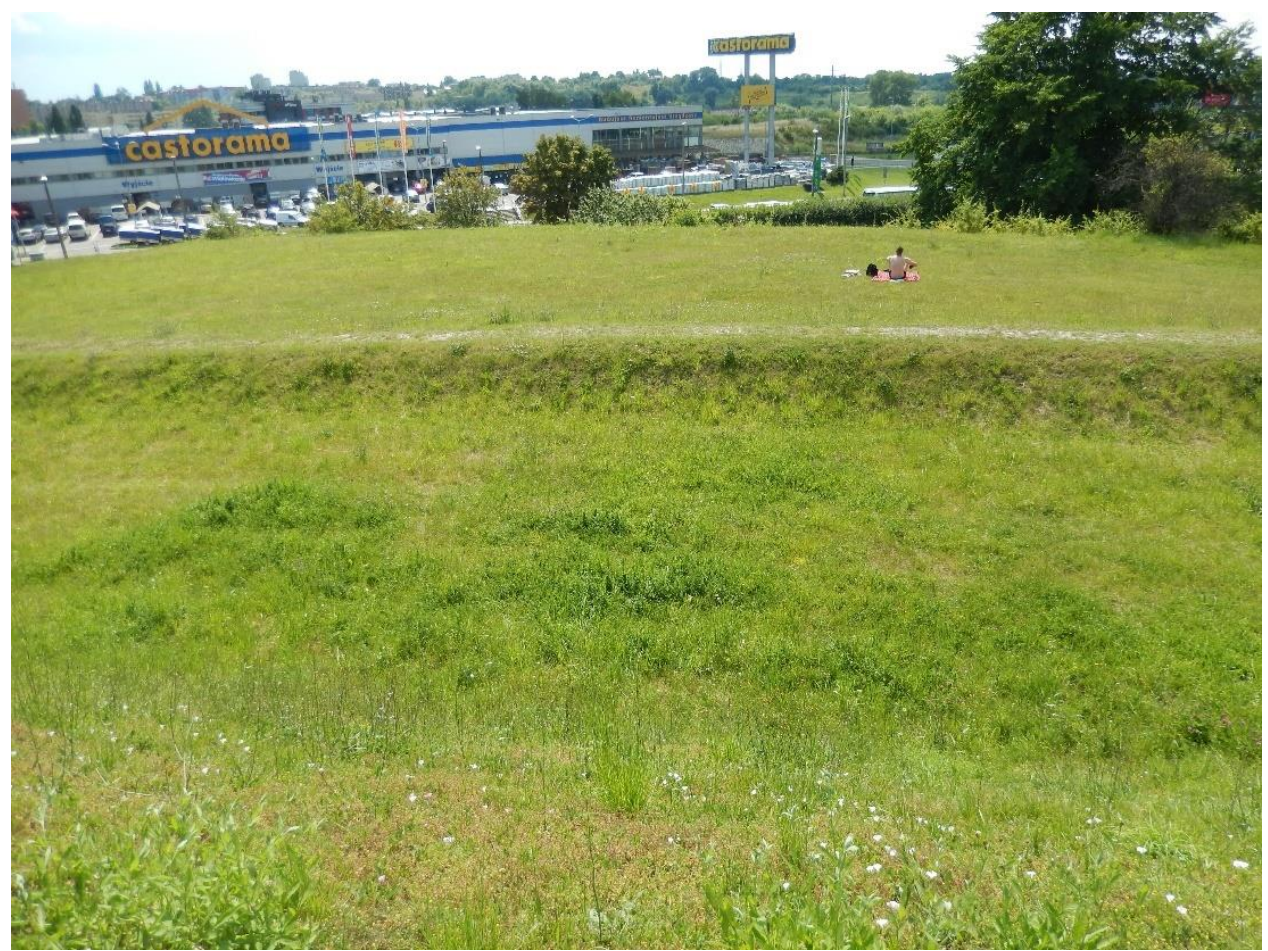

Figure 4: Sunbathers and modern development near site. Photo from author, 2014. 
In order to combat this visitor behavior, Francisco believes the museum should have included the first of the nineteen markers to post rules of acceptable behavior at the site. He listed Paneriai memorial site in Lithuania and the Memorial to the Murdered Jews of Europe in Berlin as examples of memorial spaces with posted signage. These rules protect the site from unruly behavior by prohibiting smoking and drinking, walking dogs, and using bicycles or sporting equipment. While the addition of signage at the site is a positive change, by not posting clear rules like other memorials, the museum and city are not being clear to its residents as to how to act at the site.

Other issues brought up by Francisco related to the lack of emphasis on the camp's brutality, nationality of the victims, and number of victims. He did not believe that the narrative accurately reflected the harsh treatment the prisoners received from Nazi commandant Goeth. The black and white historical photographs used for the background on the panels have been digitally manipulated to show some figures in a gold color. These figures are either prisoners or guards of the camp, varying from panel to panel. Francisco detested this manipulation, as it "has the effect of casting that history into the realm of the semi-fantastical, reinforcing the semirecognition that prevails among local attitudes." Additionally, Francisco pointed out that from the signs the chronology of the camp's events is unclear and the number of Polish to Jewish victims is not given proper context. The signs listed 30,000 as the number of prisoners of Płaszów during its lifespan in operation and 5,000 as the number of deaths. Polish historian Ryszard Kotarba placed figures for the number of prisoners in "a few tens of thousands" and during the camp's height in May and June of 1944 between 22,000 and 24,000. For the number 
of dead, Kotarba assessed a figure of 7,200. ${ }^{170}$ Most estimates support Kotarba's assessment of the number of total prisoners and dead for the former concentration camp.

The Historical Museum of Kraków has positively changed the site with the addition of the historical interpretation panels, but the interpretation itself remains inadequate. While there are some issues with the narrative's content, the existence of these panels marks a new period of memorialization for the former concentration camp. Locals who use the park can no longer deny knowledge of the historical context of the area. While the green landscape continues to be used as a park, there is an opportunity for the museum to create additional panels posting rules at the site as Francisco suggested. The museum's newly found commitment to Płaszów, as displayed through projects such as the 2016 conference and addition of interpretation panels, marks a turning point in increasing historical knowledge of the site. While the Schindler's List set confused some visitors, the increasing amount of publications and attention on the site should correct this.

${ }^{170}$ Ibid. 


\section{Conclusion}

Steven Spielberg became the unintentional memorial entrepreneur for the Płaszów concentration camp. The landscape sat largely ignored by residents and international visitors in the years after the war, until Spielberg decided to film Schindler's List in Kraków. By filming in the Liban quarry, adjacent to the Płaszów site, the project attracted many tourists to the area. These tourists either participated in film-tours from private companies or used guidebooks, such as Retracing "Schindler's List," to tour the city by themselves.

While it may not have been Spielberg's intention to become the person responsible for the preservation and commemoration movement of Płaszów, his film started the process. For a site to become a notable place, it relies on people to make it just that. Spielberg's placing of Płaszów in a cultural landscape associated with the Nazi regime, collaborators and victims, and the Holocaust transformed an abandoned site into one of great significance. While it may be impossible to preserve every space marked by a notorious past, Spielberg's reconstruction of that past in a popular film created a compelling draw to outside tourists.

The film also provided opportunities for people personally connected to the site to reflect on its significance, including descendants of Goeth and the camp's survivors. Amon Goeth was the camp commandant featured in Spielberg's film and portrayed by actor Ralph Fiennes. For Goeth's daughter and granddaughter, their main perception of him was largely influenced by Fiennes. Monika Hertwig and Jennifer Teege each discovered their relation to Goeth separately, and it prompt them to learn more about the camp. After researching and wondering about his cruel actions, they both took a personal pilgrimage to the former Płaszów camp and his villa. The film also prompted survivors to discuss their past, by publishing memoirs or guidebooks and giving tours of the site. 
The increased attention on the site because of Spielberg's film prompted the city to act. The Historical Museum of the City of Kraków’s involvement began in 2016 and was marked by three major projects. The April conference led to a publication of the same title, Discovering Płaszów, which gave an overview of historical context and previous commemorative attempts at the site. The museum's other publication about the site, KL Plaszow: Report for the Period 201617, focused on the plans towards establishing an educational museum at the site. ${ }^{171}$ In 2018 , the museum launched the digital archive for the site to collect and preserve photographs and other materials for educational purposes. ${ }^{172}$ These actions show a new commitment to commemorating the site and mark a new era of memorialization for Płaszów by a city that had previously ignored it.

The city's involvement in this preservation and commemorative process may not all be driven by ethical reasons. The local economy is driven by these sites of trauma and marketed to international tourists, largely Americans. The Auschwitz-Birkenau State Museum has consistently surpassed 2,000,000 visitors each year since $2015 .{ }^{173}$ When one considers the other local businesses, hotels, and eateries impacted by these tourists, it is clear this site holds economic importance to the region.

Spielberg's film may in fact place its own silences on this place, as this Holocaust narrative mutes the actual historical events that took place. The film includes clear "good" and "bad" characters, Oskar Schindler and Amon Goeth respectively, and ends with Schindler successfully saving his workers and Goeth being hung. This was not an accurate portrayal of the

\footnotetext{
${ }^{171}$ Bednarek, Karski, and Śmietana.

${ }^{172}$ Museum of Krakow, "Digital Archive of KL Plaszow," https://ca.muzeumkrakowa.pl/

173 "Attendance," Auschwitz-Birkenau State Museum, accessed March 1, 2020;

http://auschwitz.org/en/visiting/attendance/
} 
events of the Holocaust. Not all the perpetrators were prosecuted and sentenced. Not all the Jews were saved. Yet Schindler's List brought a narrative to American audiences that they were comfortable with, as the Allies Powers won the war and troops liberated the camps.

It did not escape my attention that this site has been impacted by the narrative of Spielberg's film. There is plenty of literature criticizing the narrative of Schindler's List, but it is not my intention to debate the successes or failures of the film. However, one cannot ignore the connection of the film's narrative to the site's narrative. American tourists, especially those who came to Poland for the early movie tours in the 1990s, may have been influenced by how Americans are identified in the film's narrative. The film only features Americans as the saving heroes and ignores the fact that America did not enter the war or involve itself until after the attack on Pearl Harbor in 1941.

Before then the landscape of Płaszów had been neglected, misinterpreted, and mistreated. Tourist companies in the mid-1990s made a profit from the commercialization of the former concentration camp. Today, local residents use the former killing ground as an area to sunbathe or fly kites. Płaszów’s evolution to a memorial site did not follow others such as Auschwitz or Madjanek, as it did not receive a museum, staff, and signage in the years following the war. More significantly, it sat largely vacant and out of public memory until Steven Spielberg filmed Schindler's List. This decision prompted a chain reaction. The film drew international tourists to the site, who in turn drew attention to the poor condition and lack of interpretation at the camp. Many of these international tourists also pointed out the improper behavior by the city's residents, who use the grounds as a park. The Historical Museum of the City of Kraków’s projects have increased historical interpretation at the site, but the improper behavior of locals remains to be a problem. 
The story of Płaszów’s landscape and interpretation fits into the larger narrative of dark tourism and film tourism. People have been drawn to the site after watching Schindler's List and want to see both the locations where Spielberg filmed scenes and those where actual historical events took place. Others may be drawn solely because of the site's historical context. Regardless of visitor motivations, the attention placed on the site can largely be traced back to Spielberg's choice to shoot the film in the area. Even more importantly, tourist companies and guidebooks would not have been able to make money from the landscape without its historical status as a former concentration camp. The ethics of using the site as such can be connected to the concept of dark tourism, when tourists are drawn to a site because of its association with darker themes, such as death.

In order for the commemoration and memorialization of a site to occur, individuals involved have to choose to interpret and commemorate a site. For Płaszów, it was largely ignored or dismissed by the local population. By the 1990s, Spielberg's film brought outsiders into the community as he drew international tourists to the site. This added attention to the site eventually prompted the city to react and its museum to get involved. While memorialization of Płaszów is increasing, local residents continue to use the former concentration camp as an area for recreational activities and chose to ignore its historical context. Prohibitive signage at entrances to the site may help but will not stop the issue of vandalism and ignorance without enhanced security and punitive countermeasures. As of this moment, none of these solutions have appeared on the horizon of Płaszów’s future. 


\section{Bibliography}

Primary Sources:

Arnold, William. "'Schindler's List' May Boost Poland Tourism." Pittsburgh Post-Gazette (PA), March 27, 1994: D-16. NewsBank: America's News. https://infoweb.newsbank.com/apps/news/documentview? $\mathrm{p}=$ NewsBank\&docref=news/0EADEFA8D9B1B9B6.

AviationGeek90. "Schindler's list camp filmshoot location - Back to concentration camp Plaszow set - Liban Quarry.” YouTube video, 8:50. December 3, 2015. https://www.youtube.com/watch?v=7-0K6_mdolA

Bednarek, Monika, Kamil Karski, and Marta Śmietana, ed. 2018. KL Plaszow: Report for the Period 2016-17. Krakow: Historical Museum of the City of Kraków. https://www.muzeumkrakowa.pl/news/memorial-site-kl-plaszow-report-for-the-period$\underline{2016-2017}$

Borger, Julian. "'Schindler's List' Draws Tourists to Krakow." Scripps Howard News Service, May 18, 1994. NewsBank: America's News. https://infoweb.newsbank.com/apps/news/documentview? $\mathrm{p}=$ NewsBank\&docref=news/0EB7AF2BE4C3DD37.

cbutchko. "plaszow-krakow quarry." YouTube video, 8:01. April 5, 2014. https://www.youtube.com/watch?v=Om2CIcZMeDE

Conroy, John. "'Schindler's List' Inspires Tours of Nazi Death Camps, Poland." Pittsburgh PostGazette (PA), July 24, 1994: K-2. NewsBank: America's News. https://infoweb.newsbank.com/apps/news/documentview? $\mathrm{p}=$ NewsBank\&docref=news/0EADF069140D1353.

Conroy, John. "Schindler's Poland: Beyond one man's heroism Grim history mingles with lasting glory in the streets and buildings of Krakow." The Kansas City Star, July 10, 1994: H1. NewsBank: America's News. https://infoweb.newsbank.com/apps/news/documentview? $\mathrm{p}=$ NewsBank\&docref=news/0EAF40A12AA75802.

Conroy, John. "Tours of Holocaust sites available." Daily Breeze (Torrance, CA), July 24, 1994 : F2. NewsBank: America's News. https://infoweb.newsbank.com/apps/news/documentview? $\mathrm{p}=$ NewsBank\&docref=news/1125C6EB813AE930.

Creative Studio. "Short story of german's Concentration Camp KL Plaszow - Kraków-Płaszów." YouTube video, 4:55. February 1, 2018. https://www.youtube.com/watch?v=GGhYGgnpPB4.

Duda, Eugeniusz. Jewish Cracow: A guide to the Jewish historical buildings and monuments of Cracow. Kraków: Vis-à-vis/ etiuda, 2003. 
dzikieswinie - Motorcycle Club and Adventures. "Amon Goeth's villa in Schindler's List (not the real house)." YouTube video, 1:01. December 7, 2014.

https://www.youtube.com/watch?v=k5L2kH3z6Eo

Fesperman, Dan. “'Schindler's List' Tour Stops at Real and Movie Sites.” Sun-Sentinel,

December 25, 1994: 8J. NewsBank: America's News.

https://infoweb.newsbank.com/apps/news/documentview? $\mathrm{p}=$ NewsBank\&docref=news/0EB4EE5EF3EEC370.

Fesperman, Dan. “In Search of 'Schindler's List.”' The Baltimore Sun, October 10, 1994. Accessed January 10, 2020. https://www.baltimoresun.com/news/bs-xpm-1994-10-101994283123-story.html.

"Grey House." In Your Pocket: Essential City Guides. March 20, 2019. Accessed April 01, 2019. https://www.inyourpocket.com/krakow/grey-house_112729v.

Gross, Eva. "Krakow-Plaszow." Interview. National WWII Museum. 2015. Accessed March 16, 2019. https://www.ww2online.org/view/eva-gross\#krakow-plaszow.

Gruber, Ruth Ellen. “Remembering Poland's Jews.” The New York Times, January 29, 1995. Accessed January 10, 2020. https://www.nytimes.com/1995/01/29/travel/rememberingpoland-s-jews.html.

Hertwig, Monika and Helen Jonas-Rosenzweig. Inheritance. Documentary. Directed by James Moll. Allentown Productions: 23 June 2006.

Hitler's Children. Directed by Chanoch Ze'evi. Film Movement, 2011.

Horowitz, Helen. "Oral history interview with Helen Horowitz." Interview. United States Holocaust Memorial Museum. May 19, 1983. Accessed March 14, 2019. https://www.iwm.org.uk/collections/item/object/80018247.

Hulkower, Benjamin. "Schindler's List: A Viewer's Guide.” Martyrs Memorial and Museum of the Holocaust, 1994.

Kagan, Joram. Hippocrene Insiders' Guide to Poland's Jewish Heritage. New York: Hippocrene Books, 1992.

Kaufman, Luna. "Nazi Brutality." Interview. National WWII Museum. 2015. Accessed March 16, 2019. https://www.ww2online.org/view/luna-kaufman\#nazi-brutality.

Kotarba, Ryszard. A Historical Guide to the German Camp in Płaszów 1942-1945. Translated by Kamil Budziarz and Dorota Plutecka. Poland: Institute of National Remembrance Commission of the Prosecution of Crimes against the Polish Nation, 2014.

Krakow Convention Bureau. "More Than 14 Million Tourists Have Visited Krakow.” Magiczny Kraków. https://www.krakow.pl/ccb_en/more_news__/235830,1441,komunikat,more_than_14_ million_tourists_have_visited_krakow.html (accessed on January 10, 2020). 
Leyson, Leon. The Boy on the Wooden Box: How the Impossible Became Possible... On Schindler's List. New York: Atheneum Books for Young Readers, 2013.

"Liban Quarry." In Your Pocket: Essential City Guides. January 20, 2019. Accessed February 01, 2019. https://www.inyourpocket.com/krakow/liban-quarry_49806v.

Marszałek, Anna, Monika Bednarek, Krystyna Stefaniak, and Piotr Krasnowolski. Oskar Schindler's Enamel Factory: Guidebook. Kraków: Muzeum Historyczne Miasta Krakowa, 2015.

Moorcroft, Andrew. "Płaszów." YouTube video, 3:30. July 31, 2006. https://www.youtube.com/watch?v=n10FZQqAZZE.

Museum of Krakow. "Digital Archive of KL Plaszow.” https://ca.muzeumkrakowa.pl/

Offen, Bernard, and Norman G Jacobs. My Hometown Concentration Camp: A Survivor's Account of Life in the Kraków Ghetto and Plaszów Concentration Camp. Library of Holocaust Testimonies. London: Vallentine Mitchell, 2008.

ozwilly. "Krakow Ghetto \& Plaszow Concentration Camp May 2012." YouTube video, 21:48. April 2, 2012. https://www.youtube.com/watch?v=5qMbQJCKd6c

Palowski, Franciszek. Retracing “Schindler's List.” Kraków: Argona Jarden, 1994.

Pemper, Mieczysław, Viktoria Hertling, and Marie Elisabeth Müller. The Road to Rescue: The Untold Story of Schindler's List. New York: Other Press, 2008.

Perlez, Jane. "FILM; Spielberg Grapples with the Horror of the Holocaust." The New York Times, June 13, 1993. Accessed January 10, 2020.

https://www.nytimes.com/1993/06/13/movies/film-spielberg-grapples-with-the-horror-ofthe-holocaust.html

Rawson, Andrew. Schindler's Krakow: The City Under the Nazis. Barnsley, South Yorkshire: Pen \& Sword Military, 2015.

Reuters. "Jews Try to Halt Auschwitz Filming." The New York Times, January 17, 1993. Accessed January 10, 2020. https://www.nytimes.com/1993/01/17/us/jews-try-to-haltauschwitz-filming.html.

Rogow, Faith. "P.O.V. Discussion Guide: Inheritance.” American Documentary Inc., 2008. http://archive.pov.org/film-files/pov_inheritance_dg_action_discussion_file_0.pdf

Salter, Mark and Jonathan Bousfield. The Rough Guide to Poland. Rough Guides, 2002.

Samsonowski, Krystyna. "Schindler's List” A Guidebook: Extermination of Cracow Jews. $4^{\text {th }}$ ed. Poland: Agencja Wydawnicza “Gestum”, 2001.

Samsonowski, Krystyna. "Schindler's List” A Guidebook: Extermination of Cracow Jews. $3^{\text {rd }}$ ed. Krakow: Agencja Wydawnicza “Gestum”, 1998. 
Schnedler, Jack. "Chicagoan Creates Tours of `Oskar Schindler's Poland'." Chicago Sun-Times, April 3, 1994: 2. NewsBank: America's News. https://infoweb.newsbank.com/apps/news/documentview? $\mathrm{p}=$ NewsBank\&docref=news/0EB421AD6350C82A.

Schnedler, Jack. "Destination Poland: The Schindler's List Tour: A journey, inspired by Spielberg's Holocaust film, through the remnants of Jewish life in Poland." Los Angeles Times, August 21, 1994. Accessed January 10, 2020. https://www.latimes.com/archives/la-xpm-1994-08-21-tr-29725-story.html.

Schnedler, Jack. "The Scenes of the Crime.” St. Petersburg Times, October 9, 1994:

5E. NewsBank: America's News. https://infoweb.newsbank.com/apps/news/documentview? $\mathrm{p}=$ NewsBank\&docref=news/0EB52D0B127A3A35.

Simons, Jake Wallis. "Who would live in a house like this? Schindler's List 'House of Horrors' where Nazi butcher Amon Göth shot Jews from the balcony and his dogs ripped victims apart is being turned into a LUXURY VILLA.” DailyMail. February 8, 2017. https://www.dailymail.co.uk/news/article-4197060/Schindler-s-List-House-Horrors.html

Strum, Beckie. "Backlash Over Nazi’s Polish Home Becoming a Luxury Villa." Mansion Global. February 9, 2017. https://www.mansionglobal.com/articles/backlash-over-nazi-spolish-home-becoming-a-luxury-villa-53671

Teege, Jennifer, and Nikola Sellmair. My Grandfather Would Have Shot Me: A Black Woman Discovers Her Family's Nazi Past. Translated by Carolin Sommer. New York: Experiment, 2016.

Terrance, Marc. Concentration Camps: A Traveler's Guide to World War II Sites. Universal Publishers, 2003.

The Associated Press. "Plaszow Camp Holocaust Monument in Poland Vandalized." March 13, 2010. https://isurvived.org/InTheNews/PlaszowCamp-vandalism.html

"Top Attractions in Krakow." TripAdvisor. Accessed November 18, 2019. https://www.tripadvisor.com/Attractions-g274772-ActivitiesKrakow_Lesser_Poland_Province_Southern_Poland.html\#FILTERED_LIST

"Travelers Can Visit Schindler's Poland." Greensboro News \& Record, June 5, 1994 : D3. NewsBank: America's News. https://infoweb.newsbank.com/apps/news/documentview? $\mathrm{p}=$ NewsBank\&docref=news/0EAF85A1D6ECBA97.

TREADER TUBE. "Exploring Nazi Death Camp (film location) Liban Quarry, Poland." YouTube video, 6:17. April 1, 2018. https://www.youtube.com/watch?v=iLytB1k4REQ

Tugend, Tom. "Spielberg, WJC Reach Agreement over Making Movie at Auschwitz." The Daily Bulletin, February 2, 1993. Accessed February 3, 2020. https://www.jta.org/1993/02/02/archive/spielberg-wjc-reach-agreement-over-makingmovie-at-auschwitz? ga=2.97846104.616566074.1582489838-1201001135.1582489837. 
Tugend, Tom. "WJC Fights Filming at Auschwitz, but Other Groups Less Concerned." The Daily Bulletin, January 22, 1993. Accessed February 3, 2020. https://www.jta.org/1993/01/22/archive/wjc-fights-filming-at-auschwitz-but-othergroups-less-concerned.

VideoHistoryToday. "Plaszow Concentration Camp.” YouTube video, 2:50. April 2, 2007. https://www.youtube.com/watch?v=DKh2dR-apk0

Williamson, Elizabeth. "Schindler's Tour Is a Moving Lesson: Movie Draws Tourists to Polish Sites.” The Wall Street Journal, August 27, 2020. Accessed January 10, 2020. https://www.wsj.com/articles/SB935766557585799207.

Winer, Stuart. "Notorious Nazi's house of horrors to become a luxury villa." The Times of Israel. February 9, 2017. https://www.timesofisrael.com/notorious-nazis-house-of-horrors-tobecome-a-luxury-villa/

Secondary Sources:

"Amon Göth." Holocaust Education and Archival Research Team. 2007. Accessed January 22, 2019. http://www.holocaustresearchproject.org/ghettos/krakow/amonGöth.html.

Bednarek, Monika, Kamil Karski, and Marta Śmietana, ed. KL Plaszow: Report for the Period 2016-17. Kraków: Historical Museum of the City of Kraków, 2018. https://www.muzeumkrakowa.pl/news/memorial-site-kl-plaszow-report-for-the-period2016-2017

Beech, John. "The Enigma of Holocaust Sites As Tourist Attractions - the Case of Buchenwald." Managing Leisure 5, 1 (2000): 29-41.

Beeton, Sue. Film-Induced Tourism. Aspects of Tourism, 25. Clevedon: Channel View Publications, 2005. https://libwvu.on.worldcat.org/oclc/62094118

Brecher, Elinor J. Schindler's Legacy: True Stories of the List Survivors. New York, N.Y.: Dutton, 1994.

Charlesworth, Andrew, and Michael Addis. "Memorialization and the Ecological Landscapes of Holocaust Sites: The Cases of Plaszów and Auschwitz-Birkenau." Landscape Research 27, 3 (2002): 229-51.

Charlesworth, Andrew. "A Corner of a Foreign Field That Is Forever Spielberg's: Understanding the Moral Landscapes of the Site of the Former Kl Plaszów, Kraków, Poland." Cultural Geographies 11, 3 (2004): 291-312.

Cole, Tim. "Crematoria, Barracks, Gateways: Survivors' Return Visits to the Memory Landscapes of Auschwitz." History and Memory: Studies in Representation of the Past 25, 2 (2013), 102-131. 
Crahay, Frédéric, and Sarah Hodgkinson. "The Concentration Camp as a Site of 'Dark Tourism'." Témoigner. Entre Histoire Et Mémoire 116, (2013): 22-32.

Drozdzewski, Danielle, Sarah De Nardi, and Emma Waterton. "Geographies of Memory, Place and Identity: Intersections in Remembering War and Conflict." Geography Compass 10, 11 (2016): 447-56. doi:10.1111/gec3.12296.

Fensch, Thomas, ed. Oskar Schindler and His List: The Man, the Book, the Film, the Holocaust and Its Survivors. $2^{\text {nd }}$ ed. Forest Dale, Vermont: New Century Books, 2014.

"Filmmaker Interview." POV. http://archive.pov.org/inheritance/interview/ (accessed December 29, 2019).

Francisco, Jason. “Clear and Not Clear Enough.” http://jasonfrancisco.net/clear-and-not-clearenough (accessed on March 10, 2020).

Freeman, Lindsey A, Benjamin Nienass, and Rachel Daniell, eds. Silence, Screen, and Spectacle: Rethinking Social Memory in the Age of Information. Remapping Cultural History, Volume 14. New York: Berghahn Books, 2014.

Gruber, Ruth Ellen. Virtually Jewish: Reinventing Jewish Culture in Europe. The S. Mark Taper Foundation Imprint in Jewish Studies. Berkeley: University of California Press, 2002.

Gruner, Wolf. Jewish Forced Labor Under the Nazis: Economic Needs and Racial Aims, 19381944. United States Holocaust Memorial Museum. New York: Cambridge University Press, 2006.

Hartman, Rudi. "Places with a Disconcerting Past: Issues and Trends in Holocaust Tourism." Europe Now, September 6, 2017. https://www.europenowjournal.org/2017/09/05/placeswith-a-disconcerting-past-issues-and-trends-in-holocaust-tourism/.

Jordan, Jennifer A. Structures of Memory: Understanding Urban Change in Berlin and Beyond. Cultural Memory in the Present. Stanford, CA: Stanford University Press, 2006.

Karski, Kamil, Różycki Sebastian, and Aleksander Schwarz. "Memories of Recent Past. Objectives and Results of Non-Invasive Archaeological Research Project at Kl Plaszow Memorial Site.” Analecta Archaeologica Ressoviensia 12 (2017): 221-46. https://doi.org/10.15584/anarres.2017.12.13.

Keneally, Thomas. Searching for Schindler. New York: Nan A. Talese, 2007.

Krisjanous, Jayne. “An Exploratory Multimodal Discourse Analysis of Dark Tourism Websites: Communicating Issues around Contested Sites." Journal of Destination Marketing \& Management 5, 4 (August 2016): 341-50. https://doi.org/10.1016/j.jdmm.2016.07.005.

Lehrer, Erica T, and Michael Meng, eds. Jewish Space in Contemporary Poland. Bloomington, Indiana: Indiana University Press, 2015.

Lehrer, Erica T. Jewish Poland Revisited: Heritage Tourism in Unquiet Places. Bloomington, IN: Indiana University Press, 2013. 
Liyanage, Sherry, J. Andres Coca-Stefaniak, and Raymond Powell. "Dark Destinations - Visitor Reflections from a Holocaust Memorial Site." International Journal of Tourism Cities 1, 4 (2015): 282-98.

Loshitzky, Yosefa. Spielberg's Holocaust: Critical Perspectives on Schindler's List. Bloomington: Indiana University Press, 1997.

Marcuse, Harold. "The Afterlife of the Camps." In Concentration Camps in Nazi Germany: The New Histories, ed. by Jane Caplan and Nikolaus Wachsmann (New York: Routledge, 2010), 186-211.

McBride, Joseph. Steven Spielberg: A Biography. 2nd ed. Jackson: University Press of Mississippi, 2010.

Megargee, Geoffrey P., ed. Encyclopedia of Camps and Ghettos, 1933-1945. Vol. 1. Part B. Bloomington, IN: Indiana University Press \& the United States Holocaust Memorial Museum, 2009.

Meng, Michael. Shattered Spaces: Encountering Jewish Ruins in Postwar Germany and Poland. Cambridge, Mass.: Harvard University Press, 2011.

Olear, Shannon, and Stephen L. Egbert. "Introduction: Geographies of Genocide." Space and Polity 13, 1 (April 2009): 1-8. https://doi.org/10.1080/13562570902780894.

Palowski, Franciszek. The Making of Schindler's List: Behind the Scenes of an Epic Film. Translated by Anna \& Robert G. Ware. Secaucus, N.J.: Carol Pub. Group, 1998.

Pedersen, Cassie. "Screening Tourist Encounters: Penal Spectatorship and the Visual Cultures of Auschwitz." The Palgrave Handbook of Prison Tourism, 2017, 131-51. https://doi.org/10.1057/978-1-137-56135-0_7.

Pedersen, Cassie. "Screening Tourist Encounters: Penal Spectatorship and the Visual Cultures of Auschwitz." The Palgrave Handbook of Prison Tourism, 2017, 131-51. https://doi.org/10.1057/978-1-137-56135-0_7.

"Plaszow Concentration Camp.” TripAdvisor. Accessed November 18, 2019. https://www.tripadvisor.com/Attraction_Review-g274772-d1206588-ReviewsPlaszow_Concentration_Camp-Krakow_Lesser_Poland_Province_Southern_Poland.html

"Plaszów - Krakow Forced Labour Camp." Holocaust Education and Archive Research Team. 2007. Accessed January 24, 2019. http://www.holocaustresearchproject.org/othercamps/plaszow/plaszow.html.

Putte, Thomas Van De. "Delineating Memoryscapes: Auschwitz versus Oświęcim.” Holocaust Studies, 2019, 1-15. https://doi.org/10.1080/17504902.2019.1625117.

Schiff, Gary S. In Search of Polin: Chasing Jewish Ghosts in Today's Poland. Washington College Studies in Religion, Politics, and Culture, V. 2. New York: Peter Lang, 2012. 
Sendyka, Roma. "Sites That Haunt: Affects and Non-Sites of Memory." East European Politics \& Societies and Cultures 30, no. 4 (2016): 687-702. doi:10.1177/0888325416658950.

Shoah Foundation. Testimony: The Legacy of Schindler's List and the USC Shoah Foundation. 1st ed. New York: Newmarket, 2014.

Śmietana, Marta and Monika Bednarek, ed. Discovering Płaszów, Kraków, Poland, April 15-16, 2016. Kraków, Poland: Historical Museum of the City of Kraków, 2019. https://www.muzeumkrakowa.pl/images/upload/Plaszow_Discovering2.pdf

Smith, David M. Moral Geographies: Ethics in a World of Difference. Edinburgh: Edinburgh University Press, 2000.

Tomala, Karolina, Florence Faber, and Papathanassis, Alexis. "The Long Tail of Tourism: Holiday Niches and Their Impact on Mainstream Tourism." Essay. In Film Tourism the Answer to Becoming Part of Your Favourite Movie? 149-58. Wiesbaden: Gabler, 2011. https://doi.org/10.1007/978-3-8349-6231-7_16.

Tunbridge, J. E, and G. J Ashworth. Dissonant Heritage: The Management of the Past as a Resource in Conflict. Chichester: J. Wiley, 1996.

United States Holocaust Memorial Museum. "KRAKOW (CRACOW).” Holocaust Encyclopedia. https://encyclopedia.ushmm.org/content/en/article/krakow-cracow (accessed on December 2, 2019).

Young, James Edward. At Memory's Edge: After-Images of the Holocaust in Contemporary Art and Architecture. New Haven: Yale University Press, 2000.

Young, James Edward. The Texture of Memory: Holocaust Memorials and Meaning. Mazal Holocaust Collection. New Haven: Yale University Pres s, 1993.

Zimmerman, Joshua D. Contested Memories: Poles and Jews during the Holocaust and Its Aftermath. New Brunswick, NJ: Rutgers University Press, 2003. 